\title{
Imbecillitas sexus
}

\section{Imbecillitas sexus}

\author{
Enrique GACTO FERNÁNDEZ \\ Catedrático de Historia del Derecho \\ Universidad de Murcia \\ egacto@um.es
}

Recibido: 4 de febrero de 2013

Aceptado: 8 de abril de 2013

\section{RESUMEN}

El artículo estudia las limitaciones impuestas a la mujer en su capacidad de obrar que, como una herencia del derecho romano, han persistido en el derecho español hasta bien entrado el siglo XIX, con ligeras variaciones. Esta discriminación jurídica por razón del sexo refleja la mentalidad dominante durante siglos en la sociedad española, de la que se ofrecen numerosos ejemplos a través de las fuentes literarias.

PALABRAS CLAVE: Mujer, discriminación sexual, historia del derecho civil, historia del derecho penal, matrimonio, familia, viudedad, adulterio.

\begin{abstract}
This article focuses on the restrictions imposed to women's independence that, as a heritage from Roman law, persisted with few variations in Spanish law until well into the XIX Century. This legal discrimination on sexist grounds reflects the mentality that prevailed in the Spanish society for centuries, illustrated many a time in literary sources.
\end{abstract}

KEYWORDS: Woman, sexism, sexual Discrimination, history of Civil Law, history ofpenal Law, marriage, family, widowhood, adultery.

\section{RÉSUMÉ}

Cet article met l'accent sur les restrictions imposées aux femmes dans leur capacité à agir, qui, comme un héritage du droit romain, ont persisté dans la législation espagnole jusqu'au XIX ${ }^{\mathrm{e}}$ siècle, avec de légères variations. Cette discrimination légale fondée sur le sexe reflète la mentalité dominante depuis des siècles dans la société espagnole, dont des nombreux exemples peuvent se réperer dans les sources littéraires.

MOTS CLÉ : Femmes, discrimination sexuelle, histoire du droit civil, histoire du droit pénal, mariage, famille, veuvage, adultère.

\section{ZUSAMMENFASSUNG}

Dieser Beitrag legt den Schwerpunkt auf die der Unabhängigkeit der Frau entgegenstehenden Restriktionen, die als Erbe des römischen Rechts, mit wenigen Varianten im spanischen Recht bis weit ins 19. Jahrhundert fortbestanden. Diese rechtliche, auf dem Geschlecht basierende Diskriminierung reflektiert die Mentalität, die in der spanischen Gesellschaft über Jahrhunderte hindurch vorherrschte und die in zahlreichen literarischen Quellen beispielhaft übermittelt wird.

SCHLÜSSELWÖRTER: Frauen, Sexismus, sexuelle Diskriminierung, Geschlechterdiskriminierung, Geschichte des Zivilrechts, Geschichte des Strafrechts, Ehe, Familie, Witwenschaft, Ehebruch. 
SUMARIO: I. Una ojeada a la Literatura. II. El horizonte jurídico. 1. El derecho civil. a) Limitaciones generales de la mujer. b) La situación de la mujer casada. c) La situación de la mujer viuda. 2. El derecho penal. a) Ventajas y desventajas de la imbecillitas seu fragilitas sexus. b) La discriminación en el adulterio. III. Hacia la igualdad.

Me he propuesto ofrecer en estas páginas una aproximación panorámica al papel que, a lo largo de la historia, el Derecho español ha atribuido a la mujer en el marco de las relaciones familiares y sociales, dos ámbitos regulados con vocación de máxima estabilidad cuyas estructuras jurídicas han evolucionado con tanta lentitud que permanecieron casi petrificadas durante más de setecientos años. Sólo en los últimos años del siglo XIX es posible advertir los primeros síntomas de una dinámica de cambio que, acelerada a partir de la segunda mitad del XX, se encuentra prácticamente rematada en la actualidad.

Así pues, la historia de las mujeres se ha mantenido durante siglos sin apenas variación. Como vamos a ver, en un mundo como éste del Derecho, donde principios e instituciones han sido concebidos y forjados únicamente por los varones desde criterios de una masculinidad excluyente, ellas han quedado confinadas en niveles de clara subordinación, reducidas casi siempre al desempeño de papeles subalternos y marginales. Su historia pudiera definirse, a la vista de esta realidad, como la historia de una larga discriminación.

La civilización occidental, en efecto, ha abordado el asunto sobre el fundamento de una mentalidad de rasgos claramente patriarcales que resultaban ya bien perceptibles en la tradición judía, que fueron fortalecidos más tarde por los planteamientos jurídicos romanos y que el pensamiento cristiano ayudaría a reforzar después todavía un poco más. De manera que en el ideario occidental, desde sus orígenes, el sexo ha venido funcionando tradicionalmente como un decisivo factor de discriminación a la hora de reconocer a las personas derechos y obligaciones jurídicamente fundamentales.

Aunque las raíces de esta cosmovisión se pierden en los orígenes de la cultura judeo-cristiana, y aunque tanto el derecho visigodo como el altomedieval ofrecen axiomáticas muestras de su persistencia, voy a partir de las concepciones generalmente aceptadas desde la baja Edad Media, época en la que por España se agudiza la difusión de ciertos principios básicos del derecho romano portadores de unos gérmenes antifeministas que, hasta fechas bien recientes, van a conservar activa toda su virulencia. Pero antes de iniciar el recorrido por el ámbito jurídico me parece interesante proponer un acercamiento a las fuentes literarias donde, como en un espejo, se encuentran reflejadas las ideas y las convicciones que dominaron en España en torno a la idiosincrasia, al temperamento y al carácter de las mujeres, prejuicios que nos ayudarán a comprender mejor el alcance de las disposiciones que encontraremos después formuladas en el entorno normativo. 


\section{Una ojeada a la Literatura}

Al ocuparse de la incidencia del sexo sobre la capacidad de obrar de las personas, la doctrina jurídica europea ha venido repitiendo, desde la baja Edad Media, un aforismo de prosapia romana que aspiraba a reflejar sintéticamente las directrices que presidían la cuestión: Son de mejor condición los varones que las hembras en lo tocante a la dignidad, y las hembras que los varones en lo tocante a la debilidad. Palpita en el adagio el convencimiento de que la simpleza y la debilidad de las mujeres (la imbecillitas seu fragilitas sexus de la que hablan los tratadistas) resultan tan evidentes que conviene tenerlas alejadas de los negocios que impliquen un cierto nivel de responsabilidades porque, dada la limitación de sus fuerzas y lo corto de su talento, el Derecho no debe someterlas a las mismas exigencias que a los varones; en atención a su congénita imbecilidad lo aconsejable es, por el contrario, que éste las favorezca con una comprensiva condescendencia que en ocasiones llega a justificar en ellas comportamientos que nunca le toleraría a los hombres.

Huellas de este tipo de ideas encontramos aquí y allá en testimonios literarios medievales y modernos, donde la inferioridad de la mujer se nos aparece consagrada ya como un sentimiento transido de reminiscencias tópicas. Cuando Cervantes, por ejemplo, la define como animal imperfecto habla a través de Lotario, un caballero rico y principal que razona desde el remanso de un relato en el que, por estar instalado al margen de las mágicas fronteras del mundo de la caballería, no hay lugar para los disparates; al contrario, la sensatez del discurso discurre con el sosiego y con la cordura a las que Cervantes nos tiene acostumbrados cuando parece expresar reflexiones propias $^{1}$.

Algo parecido sugieren los discretos parlamentos de otros personajes de la novela en los que encontramos opiniones tinturadas también con tonalidades peyorativas: ¿quién hay en el mundo que se pueda alabar que ha penetrado y sabido el confuso pensamiento y condición mudable de una mujer? se pregunta el noble Cardenio, herido por la inconstancia de Luscinda, para contestarse él mismo, con lucidez de loco entre-

\footnotetext{
${ }^{1}$ M. de Cervantes, Don Quijote de la Mancha, ed. F. Rico, Crítica, Barcelona, 2001, I. 33: "Mira, amigo, que la mujer es animal imperfecto, y que no se le han de poner embarazos donde tropiece y caiga, sino quitárselos y despejalle el camino de cualquier inconveniente, para que sin pesadumbre corra ligera a alcanzar la perfeción que le falta, que consiste en el ser virtuosa". En I. 34, sin embargo, el narrador de la novelita pondera la mayor habilidad que tienen las mujeres para salir con bien de los embrollos que ellas mismas fabrican: "[...] pero como naturalmente tiene la mujer ingenio presto para el bien y para el mal, más que el varón...”; como lo prueba la facilidad con que Camila idea la forma de mantener el engaño de su marido, recurriendo a una variante de la facecia recogida en nota 30; la misma idea, en C. de Villalón, El Crotalón, Cátedra, Madrid 1982, 239, con paternalismo condescendiente: "Porque me pareçe que es especie de extremada vileza dezir mal de mugeres, quiero callar, porque los hombres honrados antes las deben defender, por ser flaco animal". Sobre este tópico aristotélico de la mujer "animal imperfecto", refutándolo largamente como grave absurdo, B.J. Feijoo, Teatro crítico universal, Madrid 1773, I, “Discurso 16: Defensa de las Mujeres”, § II, 325-392.
} 
verado: Ninguno, por cierto $^{2}$. En una línea parecida, muchas páginas después, a Sancho no le sorprenderá en absoluto enterarse de que la hermosa Quiteria ha abandonado a Basilio para casarse con Camacho el Rico, porque entre el sí y el no de la mujer —nos dice- no me atrevería yo a poner una punta de alfiler, porque no cabría ${ }^{3}$.

$\mathrm{Y}$ al despechado Eugenio, que esconde su identidad de labrador honrado bajo la apariencia de un cabrero montaraz maldecidor de todas las hembras ${ }^{4}$, no le sirven de excusa los pocos años de Leandra para disculpar su desvergonzada fuga con el soldado seductor; sólo encontrará desahogo en decir mal de la ligereza de las mujeres, de su inconstancia, de su doble trato, de sus promesas muertas, de su fe rompida y, finalmente, del poco discurso que tienen en saber colocar sus pensamientos e intenciones que tienen 5 .

Unos cuantos peldaños más abajo en la escala zoológica, enfrascado en melancólicas cavilaciones sobre la volubilidad de la casquivana Zapaquilda, un apesadumbrado Marramaquiz acierta a sintetizar en una sola palabra (mudanza) la esencia de la mujer:

Quién pensara que fuera tan mudable/Zapaquilda cruel e inexorable/y que al galán Marramaquiz dejara/por un gato que vió de buena cara,/después de haberle dado/un pie de puerco hurtado,/pedazos de tocino y de salchichas?/¡Oh, cuán poco en las dichas/está firme el Amor y la Fortuna!/¿En qué mujer habrá firmeza alguna?/¿Quién tendrá confianza,/si quien dijo mujer dijo mudanza? ${ }^{6}$

Con espontánea sencillez, la Elvira de El mejor alcalde, el rey desvela, como si se tratara de la cosa más sencilla del mundo, la clave que permite descifrar las complejas contradicciones del espíritu femenino:

Sancho, pues tan cuerdo eres,/ advierte que las mujeres/hablamos cuando callamos,/concedemos si negamos;/ por esto, y por lo que ves,/nunca crédito nos des, /ni crüeles ni amorosas,/porque todas nuestras cosas/se han de entender al revés ${ }^{7}$.

Ser una mujer lindo animal, ¿quién habrá que lo niegue? se pregunta Lázaro de Manzanares ${ }^{8}$, y animal también (ya no imperfecto ni tampoco lindo, sino el más con-

${ }^{2}$ M. de Cervantes, Don Quijote de la Mancha, I. 27.

${ }^{3}$ M. de Cervantes, Don Quijote de la Mancha, II. 19.

${ }^{4}$ M. de Cervantes, Don Quijote de la Mancha, I. 50: “¡Ah, cerrera, cerrera, Manchada, Manchada, y cómo andáis vos estos días de pie cojo! [...] Mas ¡qué puede ser sino que sois hembra y no podéis estar sosegada, que mal haya vuestra condición y la de todas aquellas a quien imitáis!".

${ }^{5}$ M. de Cervantes, Don Quijote de la Mancha, I. 51.

${ }^{6}$ F. L. de Vega y Carpio, La gatomaquia, poema épico burlesco, $2^{\mathrm{a}}$ ed., anotada y corregida por D. Alberto Lista. Madrid, 1840, 20-21.

${ }^{7}$ F. L. de Vega y Carpio, El mejor alcalde el rey, ed. F. P. Casa y B. Primorac, Cátedra, Madrid 1993, vs. 102-110.

${ }^{8}$ J. Cortés de Tolosa, El Lazarillo de Manzanares con otras cinco novelas, ed. G. E. Sansone, EspasaCalpe, Madrid, 1974, I, cap. 16. 
trario al hombre que crió la naturaleza), es la mujer para Francisco Santos ${ }^{9}$, que remacha con el exabrupto de una décima la dilatada serie de desdichas que va sembrando a su paso por el mundo:

En fin, toda la MVGER es presagios tristes, anunciadores de desdichas, y para que veas y sepas lo que encierran en sí las cinco letras de su nombre, lee:

Muerte dice la primera/letra de su infausto nombre,/y porque más nos asombre,/Vicio la segunda encierra;/la tercera dice Guerra,/cuarta y quinta Espada y Rayo./¡A quién no causa desmayo/si es que lo quiere entender,/ver que toda la muger/es de la muerte un ensayo! ${ }^{10}$

Del soneto también, y de la muerte, echa mano Quevedo en humorístico y avinagrado trampantojo cuando revisa la idiosincrasia de la mujer:

Muy buena es la mujer, si no tuviera/ojos con que llevar tras sí a la gente,/si no tuviera lengua maldiciente,/si a las galas y afeites no se diera.//Si las manos ocultas las tuviera, $/ y$ los pies en cadena juntamente,/el corazón colgado de la frente,/que, en sospechando el mal, se le entendiera.//Muy buena si despierta de sentido,/muy buena si está sana de locura,/buena es con el gesto no raído.//Poco ofende encerrada en cueva oscura;/pero para más gloria del marido,/es buena cuando está en la sepultura ${ }^{11}$.

Esta asociación de las mujeres con la muerte se recupera en chascarrillos y en anécdotas que, con brutal franqueza, nos proporcionan idea de hasta qué punto estaba generalizada la consideración de que su nacimiento era, más que motivo de alegría familiar, un acontecimiento luctuoso:

Un vizcaíno, habiendo parido su ama, fue corriendo a pedir albricias a su amo del parto de su mujer, y cuando se lo dijo, le preguntó el amo:-¿Parió hija? Dijo el mozo: -Mejor, señor. Replicó el amo: — ¿Parió hijo? Dijo el vizcaíno: -Mejor, señor. Dijo el amo: -Pues, ¿qué parió? Respondió el vizcaíno: —Señor, una hija muerta ${ }^{12}$.

Y si la mujer, mientras hija, resultaba una carga indeseable para su padre, no digamos para los maridos, una vez casada. Alegres fueron los días de mi boda para mis

\footnotetext{
${ }^{9}$ F. Santos, Día y noche de Madrid. Discursos de lo más notable que en él pasa, ed. M. Navarro Pérez, Instituto de Estudios Madrileños, Madrid 1976, 167.

${ }^{10}$ Ibidem.

${ }^{11}$ F. de Quevedo, Poesías (“Adiciones a las Musas”, soneto 25), ed. F. Janer. BAE, Madrid, 1953, III, 493.

${ }^{12}$ Cuentos de Garibay, en A. Paz y Meliá, Sales españolas o Agudezas del ingenio nacional, BAE, Madrid, 1964, 217, donde ofrece otra versión, revestida con tintes de sucedido histórico: "Pariendo la marquesa de Elche, doña Juana de Portugal, dos hijas, la una viva, que fue doña Isabel de Cárdenas, que después fue duquesa de Feria, y la otra muerta, llevó la nueva de ello un correo al Condestable de Castilla, y pidiéndole albricias, mandóle dar cincuenta ducados, y díjole: - Mira que estos cincuenta ducados no os los doy por la viva, sino por la muerta".
} 
amigos y tristes los de mi matrimonio para mí, se lamenta Guzmán de Alfarache ${ }^{13}$. Y aunque las bromas sobre los casamientos abundan, aparecen vistos siempre, desde el punto de vista del marido, como una pesadumbre insoportable:

[...] Que no hay carga que tanto pese como uno destos matrimonios. Y así lo dio bien a sentir un pasajero, el cual, yendo navegando y sucediéndole una gran tormenta, mandó el maestre del navío que alijasen presto de las cosas de más peso para salvarse, y, tomando a su mujer en brazos, dio con ella en la mar. Queriéndolo después castigar por ello, escusábase diciendo que así se lo mandó el maestre y que no llevaba en toda su mercadería cosa que tanto pesase, y por eso lo hizo ${ }^{14}$.

Sin la cobertura jurídica que a este mercader le prestaba el derecho marítimo, hizo también echazón de su consorte (y no en la mar, sino en un río) cierto marido irritado por uno de los defectos tópicos de las mujeres: la cerril obstinación en mantener sus opiniones aún sobre las cuestiones más insustanciales; de aquí nació, según el maestro Correas, la expresión tijeretas han de ser:

En las vides son unas puntillas largas y redondas, como cordelillos, y se van retorciendo... Un proverbio hay que dice: Han de ser tijeretas, fingiendo que una mujer muy porfiada, viniendo de las viñas con su marido, puso a estas clavículas otro nombre, que debía de ser común en aquella tierra; ella porfió mucho que no se habían de llamar más que tijeretas; el marido, entrando en cólera, la echo de la puente abajo en un río, y ella iba diciendo: "-Tijeretas han de ser". Y aunque se ahogaba y el raudal de la corriente la llevaba, dando vueltas con ella, de cuando en cuando sacaba la mano afuera y, juntando los dos dedos y apartándolos, ya que no podía con la lengua, por señas daba a entender que habían de ser tijeretas ${ }^{15}$.

A esa testarudez que las arrastra a imponer siempre su criterio se acogió el pobre Sancho para excusarse cuando, rendido a la insistencia de Teresa Panza, hubo de afrontar el incómodo compromiso de pedir a su señor que le señalara un salario:

Teresa dice - dijo Sancho- que ate bien mi dedo con vuesa merced, y que hablen cartas y callen barbas, porque quien destaja no baraja, pues más vale un toma que dos te daré. Y yo digo que el consejo de la mujer es poco y el que no le toma es loco $[\ldots]$ y si me he puesto en cuentas de tanto más cuanto acerca de mi salario, ha sido

\footnotetext{
${ }^{13}$ M. Alemán, Guzmán de Alfarache, ed. F. Rico, La novela picaresca española I, Planeta, Barcelona, 1967, II.3.3: "Ellos los tuvieron buenos y se fueron a sus casas; yo quedé padeciéndolos malos en la mía...".

${ }^{14}$ M. Alemán, Guzmán de Alfarache, II. 3. 3; una variante del chiste ofrece M. de Santa Cruz, Floresta española, 9.4.6, 193.

${ }^{15} \mathrm{G}$. Correas, Vocabulario de refranes y frases proverbiales, ed. L. Combet, Bordeaux, 1967, 964a: "Tijeretas"; y en verso, F. L. de Vega y Carpio, Quien más no puede, en M. Chevalier, Cuentecillos tradicionales, 197: "Nuño: Una que echó en un pozo su marido/con los dedos formaba las tijeras,/dando a entender que muerta había vencido".
} 
por complacer a mi mujer, la cual cuando toma la mano a persuadir una cosa, no hay mazo que tanto apriete los aros de una cuba como ella aprieta a que se haga lo que quiere... ${ }^{16}$.

En el contexto de esta forma de pensar no puede extrañar la abundancia de donaires, de agudezas y de todo tipo de variaciones humorísticas sobre los imprudentes que cometen el disparate de incurrir en el matrimonio. Del siglo XVI es una ocurrencia que proponía que a tales insensatos se les aplicase la pena reservada a los bígamos:

Llevaban a un hombre a herralle en la frente por casado tres veces. Comentó un caballero: "Y aún por la primera lo merescía"17.

Un siglo más tarde, los cómicos de la legua regocijaban al público desde el escenario con letrillas como ésta, sugeridora de que el matrimonio transporta dentro de sí su propia condena:

Si recibes ofensas/de tu enemigo,/cásale. No le busques/ mayor castigo ${ }^{18}$.

El inventario de las imperfecciones y de los vicios de las mujeres pudiera alargarse todavía mucho más. Basta con repasar los doce primeros capítulos de la segunda parte del Corbacho para encontrarnos con un catálogo que circulaba desparramado por diferentes excerpta medievales y que habría de enriquecerse después por un sinfín de obras ${ }^{19}$.

A las mujeres fisgonas y «parleras», por ejemplo, se refiere más de una vez Lope de $\mathrm{Vega}^{20}$, y de la desconfianza que despertaba su afición a la charlatanería dicen bas-

${ }^{16}$ M. de Cervantes, Don Quijote de la Mancha, II. 7.
${ }^{17}$ Cuentos de Garibay, 213.
${ }^{18}$ L. Quiñones de Benavente, El tío Bartolomé, en A. Madroñal Durán, "Vida y Versos de Luis Quiñones de Benavente”, Revista de Filología Española 73, 3-4 (1993), 329. Otro ejemplo entre el sinnúmero de gracias que sintonizan con estas ideas ofrece M. de Santa Cruz, Floresta española de apotegmas o sentencias sabia y graciosamente dichas, de algunos españoles, Bruselas, 1598, 8.2.5: "Preguntando a uno que por qué, siendo él gentilhombre, se había casado con una mujer muy chiquita, respondió: —Del mal lo menos".

${ }^{19}$ A. Martínez de Toledo, Arcipreste de Talavera o Corbacho, ed. M. Gerli, Cátedra, Madrid 1987: "Segunda Parte: Aquí comienza la segunda parte de este libro en que dije que se trataría de los vicios, tachas y malas condiciones de las malas y viciosas mujeres. Las buenas en sus virtudes aprobando.- I: De los vicios y tachas y malas condiciones de las perversas mujeres, y primero digo de las avariciosas. II: De cómo la mujer es murmurante y detractadora. III: De cómo las mujeres aman a diestro y a siniestro por la gran codicia que tienen. IV: Cómo la mujer es envidiosa de cualquiera más hermosa que ella. V: Cómo la mujer según da no hay constancia en ella. VI: Cómo la mujer es cara con dos haces. VII: Cómo la mujer es desobediente. VIII: De cómo la mujer soberbia no guarda qué dice ni hace. IX: Cómo la mujer es doctada de vanagloria ventosa. X: De cómo la mujer miente jurando y perjurando. XI: Cómo se debe el hombre guardar de la mujer embriaga. XII: De cómo la mujer parlera siempre habla de hechos ajenos."; vid. notas 35 y 96, con un fragmento del capitulo VII.

${ }^{20}$ F. L. de Vega y Carpio, La noche de San Juan, vs. 253-257: "Don Luis: Retírate, Leonor, que hablar querría/a solas con don Juan. Doña Leonor: Como quisieres,/aunque la condición de las mujeres/lleva 
tante los estatutos y leyes de los ladrones franceses cuando, a principios del siglo XVII, prohibieron a los cofrades comentar con ellas cualquier asunto que se relacionara con los delicados negocios del oficio ${ }^{21}$.

Seres irracionales ${ }^{22}$, de naturaleza fácil y arrojadiza para todo lo que resulta de su gusto $^{23}$, están siempre prestas a dejarse llevar por sus inclinaciones y determinadas a perpetrar cualquier acción, por perversa que sea, cuando la consideren necesaria para la consecución de sus propósitos ${ }^{24}$.

Finea, la dama boba, se ufanaba de haber aprendido a mentir ya en el vientre de su madre ${ }^{25}$, y de haber refinado después esa innata inclinación al engaño, común a su

mal los secretos..."; vs 276-280: “Tello: No hay secreto sin espía;/las dos escuchando están,/que mujeres por saber,/y más cuando hay que temer,/ventanas en bronce harán.”; F. L. de Vega y Carpio, El perro del hortelano, ed. E. de Ochoa, Colección de los mejores Autores españoles 17, París, 1840, 58: "Anarda [a su señora la condesa Diana]: Para secretos ajenos/mucho tormento me das/sabiendo que soy mujer..."; cien años antes, Fr. A. de Guevara había ya prevenido sobre la indiscreción connatural a la mujer: "“[...] hablando comúnmente de todas, digo, que tienen más habilidad para criar hijos, que no para guardar secretos. Creedme, señor Condestable, que ni en burlas ni en veras nunca de mujeres debéis confiar cosas secretas; porque a fin de que las tengan los otros en algo, luego descubran cualquier secreto. Por muy bobos tengo yo a los maridos que esconden de sus mujeres los dineros, y les confían los secretos, porque en el dinero no hay más pérdida de la hacienda, mas en el descubrirles el secreto, a las veces les va la honra" ("Letra para el Condestable de Castilla D. Iñigo de Velasco, en la cual se toca que el hombre cuerdo no debe fiar de la mujer ningún secreto", en Epístolas familiares, Madrid, 1673, 199).

${ }^{21}$ Dr. C. García, La desordenada codicia de los bienes ajenos, ed. A. Valbuena Prat, La novela picaresca española, Aguilar, Barcelona, 1974, II, 138: "No recebimos mujeres en la compañía si no es en caso de mucha necesidad y cuando no se pudiere hacer otro, por ser naturalmente incapaces del segreto; y no pudiéndose evitar este inconveniente, estamos obligados con grandes penas a no descubrilles el cómo, de quién y cuándo."

${ }^{22}$ M. de Cervantes, Comedia famosa de la casa de los celos y selvas de Ardenia, ed. A. Valbuena Prat, Obras completas, Aguilar, Madrid 1960, 247: "Jornada II: Lauso: Eres mujer y sigues tu costumbre./ Clori: Sigo lo que es razón./ Lauso: Será milagro/hallarla en las mujeres.”; J. Cortés de Tolosa, El Lazarillo de Manzanares, cap. 16: "Discurso cerca de la mujer flaca. - [...] No sé yo quién como ella por su muerte no tenga necesidad de que la embalsamen, porque si no tiene tripas, por ser mujer es bien cierto que no tiene sesos...".

${ }^{23}$ M. de Cervantes, Novela del amante liberal, ed. F. Rico, Novelas Ejemplares, Crítica, Barcelona, 2001, 140: "Tomado, pues, entre los tres este apuntamiento, quien primero le puso en plática fue Halima, bien así como mujer, cuya naturaleza es fácil y arrojadiza para todo aquello que es de su gusto...”.

${ }^{24}$ M. de Cervantes, La española inglesa, ed. F. Rico, Novelas ejemplares, 245-246: "Con esta resolución de la reina quedó la camarera tan desconsolada, que no le replicó palabra. Y pareciéndole lo que ya le había parecido, que si no era quitando a Isabela de por medio no había de haber medio alguno que la $[\ldots]$ redujese a tener paz [...] determinó de hacer una de las mayores crueldades que pudo caber jamás en pensamiento de mujer principal, y tanto como ella lo era. Y fue su determinación matar con tósigo a Isabela; y como por la mayor parte sea la condición de las mugeres ser prestas y determinadas, aquella misma tarde atosigó a Isabela en una conserva que le dio, forzándola que la tomase, por ser buena contra las ansias de corazón que sentía...".

${ }^{25}$ F. L. de Vega y Carpio, La Dama boba, ed. A. Zamora Vicente, Espasa-Calpe, Madrid, 1969, vs. 24912513: "Finea: Demás desto, las mujeres/naturaleza tenemos/tan pronta para fingir/o con amor o con miedo,/que, antes de nacer, fingimos./ Laurencio: ¿Antes de nacer?/ Finea: Yo pienso/que en tu vida lo has oído. Escucha./ Laurencio: Ya escucho atento./ Finea: Cuando estamos en el vientre/de nuestras ma- 
género, hasta alcanzar unos niveles de sutileza y de vivacidad ante los cuales individuo tan diestro en embustes como Guzmán de Alfarache se manifiesta maravillado:

¡Qué facilidad tienen para todo! ¡Qué habilidad escotista para cualquiera cosa de su antojo! No hay juicio de mil hombres que igualen a sólo el de una mujer para fabricar una mentira de repente... ${ }^{26}$.

Muy alejada del jactancioso alarde de Finea, la Leonora de El celoso extremeño disimula bajo la apariencia de un comportamiento mojigato todo un repertorio de sinuosidades que va aflorando ante nosotros a medida que avanza la trama; moza ventanera (Sancho Panza la hubiera calado enseguida: la que es deseosa de ver, también tiene deseo de ser vista. No digo más ${ }^{27}$ ), hace buena la máxima cervantina de que no hay mujer, por retirada que esté y recatada que sea, a quien no le sobre tiempo para poner en ejecución y efecto sus atropellados deseos ${ }^{28}$. Toda la estupidez de las precauciones adoptadas por el calculador Carrizales se resume en la sentencia que Calderón, años después, pone en boca de una sencilla muchacha de pueblo:

ISABEL. Vamos, Inés/INÉs. Vamos, prima;/mas tengo por disparate/el guardar a una mujer,/si ella no quiere guardarse ${ }^{29}$.

Y la idea era ya vieja por entonces porque, siglos atrás, Sánchez de Vercial la había incorporado a su libro de ejemplos, en manifiesta demostración de la indomable perfidia femenina que al viejo celoso cervantino hubiera debido servirle de enseñanza:

[...] Un mançebo fue que toda su entençion e seso e su tiempo expendió por saber encubiertamente el arte de la mugier. E esto fecho, ovo de casar. Empero, primeramente ovo consejo del mayor sabidor de toda la comarca en que manera guardaría la mugier con que avia de casar. E el sabidor diole por consejo que feziese una

dres, hacemos/entender a nuestros padres,/para engañar sus deseos,/que somos hijos varones;/y así verás que, contentos,/acuden a sus antojos/con amores, con requiebros, /y esperando el mayorazgo/tras tantos regalos hechos,/ sale una hembra que corta/la esperanza del suceso./Según esto, si pensaron/que era varón, y hembra vieron,/antes de nacer fingimos...".

${ }^{26}$ M. Alemán, Guzmán de Alfarache, II. 3. 3; también J. Cortés de Tolosa, El Lazarillo de Manzanares, cap. 6 alude a su congénita habilidad simuladora: “[...] porque el avisado sabe que las mujeres sin maestro saben llorar, mentir y bailar..."

${ }^{27}$ M. de Cervantes, Don Quijote de la Mancha, II. 49: “[...] que la doncella honrada, la pierna quebrada, y en casa; y la mujer y la gallina, por andar se pierden aína; y la que es deseosa de ver, también tiene deseo de ser vista. No digo más". En II. 5, Teresa Panza había echado mano también de los refranes para expresar una opinión parecida: "La mujer honrada, la pierna quebrada, y en casa; y la doncella honesta, el hacer algo es su fiesta"

${ }^{28}$ M. de Cervantes, Don Quijote de la Mancha, II. 40.

${ }^{29}$ P. Calderón de la Barca, El Alcalde de Zalamea, ed. J. M. Ruano de la Haza, Espasa-Calpe, Madrid 1995, vs. 551-556. 
casa alta de paredes de piedra, e posiere dentro la mugier e le diesse asaz de comer e vestir honrradamente, e que feziesse en casa una sola puerta e non mas, sola una finiestra por donde mirasse, e la casa fuesse tan alta que ninguno non pudiesse entrar synon por la puerta.

E el mançebo caso e fizo todo lo que el sabio le aconsejara. E quando salia de casa cerrava bien la puerta, e quando entrava esso mesmo, e quando dormia ascondia la llave so su cabeça. E esto duro luengo tiempo. E un dia, yendo este mançebo al mercado, la mugier sobio a la finiestra como solia a mirar los que yvan e venian. E estando a la finiestra vio un mançebo de buen cuerpo e fermosso, e ençendiosse en amor del, e trato commo podria estar con el. E dixole que cada noche viniesse a un lugar ende açerca. E ella penso commo furtaria las llaves a su marido mientra dormiesse. E cada noche acostumbrava de dar vino al marido por lo embriagar por que mas seguramente podiesse yr al amigo por conplir su voluntad.

E el marido como avia aprendido las maldades de las mugieres, començo a pensar que alguna cosa queria fazer su mugier que le dava cada noche a bever. E una noche enfengiose ser embriago. E la mugier pensando que era assy, levantosse en camissa e fue a la puerta, e abriola, e salio al amigo. E el marido levantosse mansamente e fue a la puerta, e çerrola, e subiosse a la finiestra fasta que vio tornar a la mugier en camisa, e llamo a la puerta. E el, commo quien non sabia cossa alguna, pregunto: —¿Quién eres?

E ella demando perdon de su culpa e prometio que nunca jamas tal cosa faria. E non le aprovecho; mas ante el marido con saña dixo que nunca la tejaría entrar fasta que la demostrasse a sus parientes.

Mas ella, llamando mucho mas, dixo que sy non le abriesse la puerta, que se lançaria en un pozo que estava açerca de su casa, e assy moriria e el averia a dar quenta a sus parientes de su muerte. E el, non curando de sus amenazas, non la dexo entrar. E la mugier, llena de maldat, tomo una gran piedra e lançola en el pozo. E el marido penso que su mugier se avia lançado dentro e salio apriessa, e fue al pozo pensando que era verdat que avia caydo en el pozo.

E la mugier, desque vio la puerta abierta, fue luego ante que el marido, e entro en casa e çerro la puerta, e sobiosse a la ventana. E el veyendosse engañado, dixo: - ¡O mugier engañosa e llena de arte del diablo! Dexame entrar, e yo te perdonare el mal que me has fecho.

Ella maltrayendolo con juramento dixo que non le dexaria entrar e deziendo: - ¡O engañador malo! Yo mostrare tu maldat e quien tu eres a tus parientes, que cada noche te levantas furtiblemente e vas al burdel donde estan las putas. E llamo otro dia a los parientes e dixogelo assy. E ellos creyendo, rreprehendieronle mucho.

E assy ella con su maldat, el pecado que ella avia fecho rretorquiolo sobre su marido, e mas: dixo que non faria vida con el si non se emendasse e non la segurasse. E el assi lo fizo. E assy aprovecho la gran guarda de la mugier e lo que avia deprendido ${ }^{30}$.

${ }^{30}$ C. Sánchez de Vercial, Libro de los exenplos por a.b.c., ed. J. Keller, Madrid 1961, 303; G. Correas, Vocabulario de refranes y frases proverbiales, 509b-510a encarece la astucia con que las mujeres resuelven estas situaciones: "Tras cornudo, apaleado, y ambos satisfechos".- El amo, de la fidelidad de la mujer y mozo, y el mozo, de haber gozado a la señora. Dicen este chiste: que la ama dijo al mozo que 
Algunas voces aisladas disonaron de este general sentir que sobre la inferioridad de las mujeres dominó en la España de los Austria; como la de Lope de Vega o la de María de Zayas, dos autores que más de una vez tuvieron ocasión de manifestarse su admiración recíproca y su simpatía y que encontraron en esta cuestión un punto de afinidad. Reivindicación de la mujer circunstancial en Lope (tan certero ahora en el diagnóstico de las causas que han extendido la desdeñosa opinión generalizada como agudo se mostraba cuando unía su voz al coro de las descalificaciones):

LAURA: Por volver por mi opinión/os la diré. Estadme atento./Antes, generoso Arnaldo/que a las artes liberales/diese principio, ni hubiese/ocasión para indignarme,/ había dado en leer/los libros más principales/de historias y de poesías/y de tragedias de amantes./Hallaba en todos los hombres/tan fuertes, $\tan$ arrogantes,/tan señores, tan altivos,/tan libres en todas partes,/que de tristeza pensé/morirme, y dije una tarde/a una dama a quien solía/comunicar mis pesares:/«Filida, ¿qué puede ser/que en cualquier parte que traten/ de mujeres, ellas son/ las adúlteras, las fáciles,/las locas, las insufribles,/las varias, las inconstantes,/las que tienen menos ser/y siguen sus libertades?»./«Eso (Filida me dijo),/Laura, solamente nace,/de ser dueños de la pluma;/de cualquiera acción que hacen... ${ }^{31}$.

Y expresada de manera más vehemente y combativa, con tintes de feminismo militante, en el caso de la escritora:

[...] han dado los hombres en una opinión, por no decir flaqueza, en ser contra ellas [las mujeres], hablando y escribiendo como si en todo tiempo no hubiera habido de todo, buenas mujeres y buenos hombres, y, al contrario, malas y malos, que se verá un libro y se oirá una comedia y no hallarán en él ni en ella una mujer inocente, ni un hombre falso. Toda la carga de las culpas es al sexo femenil, como si no fuese mayor la del hombre [...] y si se mira bien, la culpa de las mujeres la causan los hombres. ${ }^{32}$

fuese tras la cama a ella en durmiéndose el marido; estándolo ya, y teniéndole asido por la mano, despertó al marido, y díjole que el mozo la había requerido, y que le dijo que sí, que le esperaría en el corral. Que él se vistiese los vestidos de ella y le fuese a esperar y le castigase. Fue el buen hombre engañado; luego entró el mozo en la cama y el amo a esperar. En negociando, fue el mozo con un garrote, haciendo del fiel, y apaleó al amo embarazado con la saya, como que fuera el ama, diciendo: — ¡Bellaca! ¿a mi señor había yo de hacer tal agravio, ni vos traición? Y recogióse con esto, y el amo quedó apaleado, burlado y satisfecho". La historieta sintoniza con el exemplum XI (De gladio) de la Disciplina clericalis donde el adúltero es homenajeado por el marido, que — menos mal- aquí no sale malparado; hay otras variantes ponderativas de la sagacidad con que las mujeres saben resolver estos sobresaltos en IX (exemplum de vindemiatore), y en X (exemplum de lintheo) y XIII (exemplum de canicula lacrimante), en los que hacen aparición sendas Celestinas avant la lettre.

${ }^{31}$ F. L. de Vega y Carpio, La vengadora de las mujeres, ed. J.A. Hormigón, Madrid 1986, vs. 51-80.

${ }^{32}$ M. Zayas, El verdugo de su esposa, ed. E. Ruiz-Gálvez, en Obras Completas, Fundación José Antonio de Castro, Madrid, 2001, 478. 
Pero se trata de manifestaciones inusuales en medio de un mare mágnum de reprimendas. Al margen, en fin, de jocosidades y de chistes más o menos graciosos, en tono ya de mayor profundidad meditativa, valgan como cierre de nuestra inmersión en los contornos literarios las reflexiones que deja apuntadas Quevedo en su Vida de Marco Bruto:

Es la mujer compañía forzosa que se ha de guardar con recato, se ha de gozar con amor y se ha de comunicar con sospecha. Si las tratan bien, algunas son malas. Si las tratan mal, muchas son peores. Aquél es avisado, que usa de sus caricias y no se fía dellas....33

... Son artífices y oficinas de la vida [porque se gesta en su vientre], y ocasiones y causas de la muerte. Hánse de tratar como el fuego... Son nuestro calor, no se puede negar; son nuestro abrigo; son hermosas y resplandecientes: vistas, alegran las casas y las ciudades; mas guárdense con peligro, porque encienden cualquier cosa que se les llega; abrasan a lo que se juntan, consumen cualquier espíritu de que se apoderan, tienen luz y humo con que hacen llorar su propio resplandor.

Quien no las tiene, está a escuras; quien las tiene, está a riesgo; no se remedian con lo mucho ni con lo poco: al fuego poca agua le enciende, mas mucha le ahoga luego; fácilmente se tiene, y fácilmente se pierde. La comparación propia me excusa el verificarlas; porque fuego y mujer son tan uno, que no trueca los nombres quien al fuego llama mujer, y a la mujer fuego ${ }^{34}$.

\section{El horizonte jurídico}

Como es natural, las esencias de este pensamiento que, como acabamos de ver, impregna de misoginia la mentalidad española desde época medieval (y que satura de ejemplos la narrativa didáctica de la época) ${ }^{35}$ encontraron lógico acomodo en el ámbito normativo, de manera que resulta fácil descubrir su reflejo en la mayor parte de las instituciones jurídicas. Porque, siendo el Derecho una manifestación de la cultura en cuyo seno rige, sus normas traducen los idearios sociales de su tiempo, a los que viene a dar vestidura legal.

\section{El derecho civil}

a) Limitaciones generales de la mujer

Ya las Partidas, una de las piedras angulares del derecho civil castellano a lo largo de todo el Antiguo Régimen, consignan el siguiente axioma al tratar sobre el estado de las personas:

\footnotetext{
${ }^{33}$ F. de Quevedo, Vida de Marco Bruto, Espasa-Calpe, Buenos Aires, 1950, 21-22.

${ }^{34}$ Ibidem, 37.

${ }^{35}$ Entre los más conocidos, El Libro de los exenplos por a.b.c, El Libro de Buen Amor, El Libro de los gatos, El Libro de los buenos proverbios, Bocados de oro, etc., etc. Resulta mucho más expresiva todavía, por más chocarrera, la literatura paremiológica, cuyos mensajes desparraman a diestro y siniestro groserías, sarcasmos, desprecio y aborrecimiento a las mujeres.
} 
Otrosí, de mejor condición es el varón que la muger en muchas cosas, e en muchas maneras, assí como se muestra abiertamente en las leyes deste nuestro Libro que fablan de todas estas razones ${ }^{36}$.

La formulación de este principio va a concretarse, para empezar, en el tratamiento de los dos momentos críticos de la existencia humana: el del nacimiento y el de la muerte. Cuando en ellos concurren seres de uno y otro sexo, entran en juego sendas presunciones de rancio abolengo romano que tendrán trascendentales secuelas en el marco del derecho sucesorio y una dilatada vigencia en el ordenamiento jurídico español:

Por lo que respecta al nacimiento, se consagra el principio de que la primogenitura, en supuestos de parto múltiple, corresponde siempre al varón. Las Partidas lo reconocieron así:

Nascen a las vegadas dos criaturas del vientre de alguna muger, e contesce que es dubda qual dellas nasce primero. E dezimos, que si uno es varón e el otro fembra, que devemos entender que el varón salió primero... ${ }^{37}$.

A continuación, prolongando la misma filosofía, la norma se refiere al problema de la premoriencia, resolviendo que, en caso de muerte de los cónyuges en un mismo accidente, el Derecho considera que la vida de la mujer se extingue antes que la del hombre:

Otrosi dezimos, que muriendo el marido e la muger en alguna nave que se quebranta en la mar, o en torre o en casa que se encendiesse fuego, o que se cayesse, entendemos que la muger, porque es flaca naturalmente, moriría primero que el varón: e tiene pro saber esto, por razon de las donaciones, que el marido, e la muger, fazen el uno al otro en su vida; e por las posturas e los pleytos, que ponen entre si, en razon de las dotes e de las arras... ${ }^{38}$.

A esta postergación de la mujer, cimentada en el presupuesto de su menor fortaleza física, vendrían a sumarse otras limitaciones que se fundan en la desconfianza que el legislador alberga acerca de su capacidad de discernimiento o que traen su origen en arraigadas aprensiones acerca de la índole moral del alma femenina (porque son las mugeres naturalmente cobdiçiosas e avariciosas, sentencia una ley de Partidas que pervive en ecos literarios varios siglos después) ${ }^{39}$.

\footnotetext{
${ }^{36}$ Partidas, ed. Los Códigos españoles concordados y anotados, III, Madrid, M. Rivadeneyra, 1848, 4.23.2: "En quantas cosas se departe la fuerça del estado de los omes".

${ }^{37}$ Partidas, ed. Los Códigos españoles concordados y anotados, IV, 7.33.12: "De las cosas dubdosas que acaescen en razon del nascimiento de los niños, e de la muerte de los omes".

${ }^{38}$ Ibidem.

${ }^{39}$ Partidas 4.11.3: "De la donacion que faze el esposo a la esposa, o ella a el, assi como joyas, o de otras cosas. - "Sponsalitia largitas en latin, tanto quiere dezir en romance, como don que da el esposo a la esposa, o ella a el, francamente sin condicion, ante que el matrimonio sea cumplido por palabras de pre-
} 
Por ello, y en virtud de esta pretendida imbecillitas, las mujeres no pudieron ser, durante siglos, testigos en los testamentos, ni constituir fianzas en favor de terceros ni tampoco comparecer ante los tribunales en los juicios civiles, y sólo muy excepcionalmente en los criminales. En el ámbito del derecho administrativo la limitación de su capacidad de obrar encontraría reflejo paradigmático en la prohibición de desempeñar oficios o cargos públicos que llevaran aparejada jurisdicción, y en la de ejercer los empleos de abogado y de procurador, profesiones que quedaban fuera de su alcance porque, como expresan las Partidas, quando las mugeres pierden la vergüença, es fuerte cosa el oyrlas, e el contender con ellas ${ }^{40}$. En humorística paradoja, siglos después oiremos comentar a don Quijote, para quien esta limitación no podía resultar desconocida, que saben todos que las armas de los togados son las mesmas que las de la mujer, que son la lengua ${ }^{41}$.

Supervivencia de esta mentalidad es, sin duda, la preterición de la primogénita del rey en beneficio de sus hermanos varones a la hora de suceder en el trono, principio de polémica trayectoria a lo largo del derecho histórico español que encontramos alojado todavía en el artículo 57.1 de nuestra Constitución ${ }^{42}$, a despecho de la tajante consagración de la igualdad de sexos que proclama el artículo 14 y que, de vez en cuando, suscita algunas inquietudes ${ }^{43}$. Da la impresión de que todavía tiene hoy al-

sente [...] E si acesciesse, que la esposa fiziese don a su esposo, que es cosa que pocas vegadas aviene, porque son las mugeres naturalmente cobdiçiosas, e avariciosas...; M. Alemán, Guzmán de Alfarache, III, 1: “[...] Siempre les paresce poco lo mucho que reciben y mucho lo poco que dan. Son por lo general avarientas...".

${ }^{40}$ Partidas, ed. Los Códigos españoles concordados y anotados, IV, 3.6.3: "Quien no puede abogar por otri, e puedelo fazer por si.- Ninguna muger, quanto quier que sea sabidora, non puede ser abogado en juyzio por otri. E esto por dos razones. La primera, porque non es guisada, nin honesta cosa, que la muger tome officio de varon, estando publicamente embuelta con los omes, para razonar por otri. La segunda, porque antiguamente lo defendieron los Sabios, por una muger que dezian Calfurnia, que era sabidora: porque era tan desvergonçada, que enojava a los Jueces con sus bozes, que non podian con ella. Onde ellos, catando la primera razon que diximos en esta ley, e otrossi veyendo que quando las mugeres pierden la vergüença, es fuerte cosa el oyrlas, e el contender con ellas; e tomado escarmiento, del mal que sufrieron de las bozes de Calfurnia, defendieron que ninguna muger non pudiesse razonar por otri..."; todavía a principios del siglo XIX un ilustrado como Juan Antonio Llorente justificaba las limitaciones impuestas a las mujeres en sede procesal: "Porque las mujeres son volubles, mentirosas, fraudulentas, engañadoras, superficiales y corruptibles, como múltiples autores han demostrado, su testimonio no se admite en los tribunales a no ser que se trate de un crimen gravísimo".

${ }^{41}$ M. de Cervantes, Don Quijote de la Mancha, II.32; probablemente de aquí toma la cita J. Cortés de Tolosa, El Lazarillo de Manzanares, cap. 16: "Las armas de las mujeres oí decir siempre que eran la lengua...".

${ }^{42}$ Constitución española, 57.1. "La Corona de España es hereditaria en los sucesores de S.M. Don Juan Carlos I de Borbón, legítimo heredero de la dinastía histórica. La sucesión en el trono seguirá el orden regular de primogenitura y representación, siendo preferida siempre la línea anterior a las posteriores; en la misma línea, el grado más próximo al más remoto; en el mismo grado, el varón a la mujer, y en el mismo sexo, la persona de más edad a la de menos".

${ }^{43}$ Convendría apuntar, a propósito de las frecuentes incitaciones a la reforma de este artículo, que la aceptación de la monarquía, en lo que tiene de opción política, resulta tan respetable como su rechazo, 
guna actualidad la reflexión que hace cuatrocientos años se hacía un ilustre jurista castellano, Castillo de Bobadilla:

En estos reinos y monarquías sabemos por historias sagradas y profanas que han reinado mugeres, y gobernado admirablemente aunque, como cosa rara, [esto] no se ha de imitar, y háse de temer ${ }^{44}$.

\section{b) La situación de la mujer casada}

En el ámbito del matrimonio y en el de la familia, y a lo largo también de todo el Antiguo Régimen, la comunidad doméstica aparece diseñada desde una concepción patriarcal en la que el hombre monopoliza todos los poderes básicos, asumiendo funciones supremas de gobierno y de mando que relegan a los restantes miembros, y entre ellos a la mujer, a posiciones subalternas de pasiva sumisión. En todos los asuntos familiares, la última ( $\mathrm{y}$ a veces también la única) palabra le corresponde siempre al cónyuge varón, como marido y como padre.

Así, ante la mujer, el marido asume un papel protector y directivo que la doctrina ha venido justificando por la necesidad de amparo en que aquélla se encuentra, dada su debilidad, su falta de experiencia y, por tanto, su facilidad para incurrir en error ${ }^{45}$. El principio, indiscutido a lo largo de la Historia, recibe todavía formulación moderna en nuestro Código civil: El marido debe proteger a la mujer y ésta obedecer al marido ${ }^{46}$, un deber de obediencia que encuentra derivación inmediata, como primera secuela lógica, en la facultad que le asiste al hombre de fijar libremente el domicilio conyugal, facultad reconocida a continuación: La mujer está obligada a seguir a su marido donde quiera que fije su residencia a no ser que los Tribunales, con justa causa, la eximan de esta obligación ${ }^{47}$.

siempre que no se pretenda desnaturalizar su intrínseco anacronismo mediante acicalamientos disimulen ésta y otras clamorosas discordancias del Título II con diferentes preceptos constitucionales. En mi opinión, los intentos de acomodarla a los principios jurídicos actuales harían de ella una criatura de Frankenstein institucional.

${ }^{44} \mathrm{~J}$. Castillo de Bovadilla, Política para Corregidores y señores de vasallos, en tiempo de paz, y de guerra, ed. Instituto de Estudios de Administración Local, Madrid, 1978, II.16.225.

${ }^{45}$ J. M. Manresa, Comentarios al Código civil español, Madrid, 1890-1905, I, 268, sobre la idea de F. García Goyena, Concordancias, motivos y comentarios del Código civil español, Madrid, 1852, art. 58 de su Proyecto: "Si el marido, más fuerte por su sexo, y como gefe y cabeza de la familia, por la ley debe proteger a la muger, síguese que ésta deba obediencia al marido. Es un homenaje tributado al poder protector, y una consecuencia necesaria de la sociedad conyugal que no podría subsistir si uno de los esposos no estuviera subordinado al otro".

${ }^{46}$ Código civil, art. 57; B. Gutiérrez, Códigos o Leyes fundamentales sobre el derecho civil español, Madrid, 1871, I, 413.: "Que el marido debe proteger a la muger, y esta obedecer al marido, lo exige aun sin decirlo la ley, su diferente complexión. El varón representa la fuerza: la solicitud que hace llevaderas las atenciones de la familia es el encargo de la muger; su debilidad la constituye en un estado de racional dependencia, pero no en el esclavitud...".

${ }^{47}$ Código civil, art. 58: "La mujer está obligada a seguir a su marido donde quiera que fije su residencia. Los Tribunales, sin embargo, podrán con justa causa eximirla de esta obligación cuando el marido tras- 
De la parsimonia con la que los jueces deberían administrar las dispensas de esta obligación de acompañamiento opina así uno de los redactores del Código:

Claro es que no ha de autorizarse la excepción de un precepto tan de esencia en el matrimonio como es la vida en común, en fútiles pretextos, en caprichos femeniles o en fantásticas repugnancias y temores. Nuestros tribunales deben utilizar la facultad que el artículo 58 les concede de forma parca y prudente, y en casos muy determinados. Una enfermedad grave de la mujer o de un hijo, el abandono por el marido del hogar conyugal para emprender una vida errante y vagabunda, pudieran ser motivo suficiente para otorgarla ${ }^{48}$.

Obediencia y sometimiento, por tanto, de la mujer al marido en sus relaciones personales. En el ejercicio de esta función tutelar masculina, que no se diferencia prácticamente de la que, como padre, ejerce sobre los hijos (y por ello el derecho romano situaba a la mujer in loco filiae, ocupando en la casa el lugar de una hija ${ }^{49}$ ), el marido va a ostentar, desde la Edad Media hasta la promulgación del Código civil, un derecho de corrección, un ius correctionis que, en opinión de la doctrina, incluye la potestad de administrar castigos físicos a la esposa cada vez que ésta diera motivos para ello. Maltratos de este tipo salpican nuestra literatura, relatados con una naturalidad que denota el carácter cotidiano de tales escenas o, desdramatizando más, en tono burlesco como el que registra el maestro Correas para ilustrar el origen de la expresión todo se andará:

Todo se andará.- Apaleaba uno a su mujer y le daba en la cabeza. Díjole ella que diese en otras partes, él replicó: - Todo se andará, si el palo no se quiebra ${ }^{50}$.

lade su residencia a ultramar o a país extranjero"; F. García Goyena, Concordancias, motivos y comentarios, art. 59: "Según la opinión de algunos autores, la muger no está obligada a seguir al marido con peligro de su vida; por ejemplo, embarcándose; y de aquí procede que no se admitan memoriales de hombres casados en solicitud de plazas o destinos de ambas Américas sin escritura formal de las mugeres, dándoles licencia para aquellas solicitudes, obligándose a seguirles [...]”; B. Gutiérrez, Códigos o Leyes fundamentales I, 415: "Mas la muger que obstinadamente y sin fundamento se negase a seguir al marido al punto donde fijase su residencia, queda privada del derecho a los alimentos y de los beneficios de la sociedad conyugal, según resuelven los prácticos".

${ }^{48}$ J. M. Manresa, Comentarios al Código civil español, I, 270; F. García Goyena, Concordancias, motivos y comentarios, art. 59: “[...] los tribunales deberán ser muy circunspectos y económicos en el uso de esta facultad discrecional [...]".

${ }^{49}$ F. García Goyena, en sus Concordancias, motivos y comentarios, presupone la idea de forma reiterada: art, 62: “[...] bajo el aspecto legal, la muger casada, como por un comun acuerdo de todos los legisladores, viene a ser una verdadera menor de edad [...] la muger tiene el concepto de menor de edad [... ], el marido es como su curador, el gefe de la sociedad..."; art. 826: "La muger casada viene a ser por las leyes un menor de edad privado del consejo de familia..."; art. 987: “[...] la muger casada viene a quedar como en el concepto de menor...".

${ }^{50}$ G. Correas, Vocabulario de refrane y frases proverbiales, 964a: "Todo se andará". 
Ciertamente hay que reconocer que, al expresar su parecer sobre este punto, los juristas del Seiscientos precisaban que los castigos debían ser moderados, por lo cual condenaron unánimemente las llamadas palizas atroces y desmesuradas, entendiendo por tales (con su característico casuismo) las que se propinaran con palos, látigos, correas, sogas, garrotes o bastones, sobre todo si éstos se rompían a lo largo del castigo, o si los golpes se concentraban en la cara y en la cabeza, o si provocaban copiosa efusión de sangre ${ }^{51}$. Pero también hay que destacar que hasta los autores más comedidos no tuvieron ningún reparo en justificar estos vapuleos en caso de excepcional malicia de la esposa como, por ejemplo, en el supuesto de haberla sorprendido en adulterio ${ }^{52}$.

Todavía en los últimos años del siglo XIX la civilística continuaba atribuyendo al varón este mesurado derecho de corrección en el que, a diferencia de lo que había defendido la doctrina tradicional, no consideraron ya incluidos los castigos físicos ${ }^{53}$. En consecuencia, entre las causas legítimas de divorcio el Código civil mencionará "los malos tratamientos de obra o las injurias graves" ${ }^{4}$, solución que dejó persuadidos a sus redactores de que habían superado ya arcaicas concepciones tradicionales. Como escribe uno de ellos,

Bajo tres principios distintos es hoy posible desarrollar el régimen de familia, pudiendo ser conocidas las teorías más admitidas merced a la clasificación siguiente: Primera. Teoría de la tradición, en la cual se afirma la inferioridad de la mujer respecto al hombre. Segunda. Teoría del sentimentalismo, que proclama caballeresca y galantemente la igualdad de la mujer con el marido. Tercera, teoría científica, que no admite predominio del varón sobre la hembra, pero tampoco la igualdad entre los dos sexos. En esta última se fundamenta la mayor parte de las legislaciones modernas ${ }^{55}$.

Aún la Ley de Matrimonio civil de 1870 registraría una manifestación del imperio marital que, sin precedentes en la tradición jurídica española, resultó criticada por la doctrina:

\footnotetext{
${ }^{51}$ P. Farinaccio, Praxis et Theoricae criminalis, Lugduni 1613, Pars quarta, Quaestio 143: "Vir an et quomodo possit uxorem suam verberare", § verberatio, nº 182 y 191.

${ }^{52}$ P. Farinaccio, Praxis et Theoricae criminalis. Pars quarta. Quaestio $143 \S$ verberatio, no 185: “[...] causa potest esse tam magna, ut vir impune possit uxorem suam etiam atrociter et immodetarte verberare, ut puta si eam deprehendat in adulterio [...], tunc enim [...] maritus verberando uxorem etiam immoderate nullam poenam mereatur...".

${ }^{53}$ En este sentido ya, por ejemplo, F. García Goyena, Concordancias, motivos y comentarios, art. 58, sobre el derecho modice castigandi uxori del marido: "[...] yo entiendo que debe competirle en cuanto sea necesario para mantener el buen orden de la familia, del que es responsable: al que se impone una obligación, se le conceden los medios necesarios para desempeñarla."; M. Falcón, Exposición doctrinal del Derecho civil español, común y foral, Salamanca 1878, I, 210: "No es el marido en la familia española aquel déspota que en la familia romana se conocía con el nombre de pater-familias; pero sin ser dueño de poder tan absoluto tiene en su autoridad atribuciones bastantes para el gobierno de esa pequeña sociedad de que es fundador y jefe. No legisla como un soberano, pero le está reservado arreglar el orden, gastos y costumbres de su casa...".

${ }^{54}$ Código civil, art.105.

${ }^{55}$ J. M. Manresa, Comentarios al Código civil español, I.268.
} 
Tampoco podrá la mujer publicar escritos, ni obras científicas ni literarias de que fuere autora o traductora, sin licencia de su marido, o en su defecto, sin autorización judicial competente. ${ }^{56}$

En relación con las personas de sus hijos, la mujer quedó apartada durante siglos del derecho a educarlos, a corregirlos y a consentir en su matrimonio, facultades que correspondían exclusivamente al marido, en su calidad de padre ${ }^{57}$.

Desde el punto de vista patrimonial, el Código civil impuso el régimen castellano de la sociedad de gananciales, generalizándolo con carácter legal a falta de estipulaciones matrimoniales que establecieran otro distinto ${ }^{58}$. Con arreglo a este sistema, el gobierno económico del matrimonio quedaba concentrado del todo en manos del hombre, lo que determinó que la mujer se convirtiera en mera espectadora del control ejercido por el marido sobre la fortuna familiar, e incluso sobre sus propios bienes personales.

Porque al marido le competía la administración de todos los bienes adquiridos después de la boda, de los llamados bienes gananciales, cuya titularidad se atribuye a cada cónyuge por mitad pero sobre los cuales aquél tiene reconocida una capacidad dispositiva plena, sin ninguna limitación:

Siendo el hombre más fuerte [escribe todavía a fines del siglo XIX uno de los comentaristas del Código civil], siendo más enérgico, más en relación con la sociedad y con el mundo exterior, y estando más desligado de los deberes domésticos, se encuentra, desde luego, en mejores condiciones para llevar la dirección de la casa. El

\footnotetext{
${ }^{56}$ Ley de Matrimonio civil de 1870, 52; por ejemplo, M. Falcón, Exposición doctrinal del Derecho civil español, I, 222: "No parece sino que se ha dictado ex profeso para humillar a las mujeres que en nuestro país se dedican al cultivo de las ciencias o de las letras [...] ¿Qué se ha temido, qué se ha querido evitar con esa disposición tan extraña? [...] Nos es imposible averiguar sus motivos. Mientras éstos permanezcan ocultos, hemos de creer una condición irritante para la mujer la humillación a que se la somete. La mujer casada debe a su marido su fe, su afecto, sus dulces cuidados, su tiempo, su existencia entera; pero no le debe su talento. La vida de la ciencia es suya: suya propia la gloria que pueda en ella conquistar. No hay razón para que se sujete también al poder del marido una vida que ni se ha ofrecido ni es necesaria para los fines naturales del matrimonio".

${ }^{57}$ Partidas 4.17.2: "Sobre quales fijos non ha este poder el padre.- [...] E como quier que el padre aya en poder sus fijos legitimos, o sus nietos o visnietos que descienden de sus fijos; non se debe entender por esso, que los puede aver en poder la madre, nin ninguno de los otros parientes de parte de la madre..."; Código civil, art. 154: "El padre, y en su defecto la madre, tienen potestad sobre sus hijos legítimos no emancipados..."; 155: "El padre, y en su defecto la madre, tienen, respecto de sus hijos no emancipados: $1^{\circ}$. El deber de alimentarlos, tenerlos en su compañía, educarlos e instruirlos con arreglo a su fortuna [...] $2^{\circ}$. La facultad de corregirlos y castigarlos moderadamente."; 45: "Está prohibido el matrimonio: $1^{\circ}$. Al menor de edad que no haya obtenido la licencia ... de las personas a quienes corresponda otorgarla..."; 46: "La licencia de que habla el $n^{\circ} 1^{\circ}$ del artículo anterior, debe ser concedida a los hijos legítimos por el padre; faltando éste, o hallándose impedido, corresponde otorgarla, por su orden, a la madre, a los abuelos paterno y materno...".

${ }^{58}$ Código civil, art. 1.316.
} 
marido es el jefe de la familia por acuerdo unánime de todas las legislaciones antiguas y modernas ${ }^{59}$.

En consecuencia con este planteamiento, la mujer no puede disponer de los bienes familiares sin licencia del marido, mientras que la capacidad de disposición reconocida a éste es, por el contrario, prácticamente ilimitada, de modo que puede hacer con los bienes gananciales lo que le dé la gana: puede vender los muebles y los inmuebles, hipotecarlos, darlos en prenda, arrendarlos, constituir sobre ellos derechos de usufructo o servidumbres, y obligarse en cualquier otro modo con absoluta libertad matrimonio constante. Únicamente se le prohíbe realizar operaciones que perjudiquen al patrimonio en fraude de la familia, esto es, con dolo. O disponer de estos bienes a título lucrativo, es decir, donarlos ${ }^{60}$.

Fuera de estos dos supuestos, no hay controles. La doctrina había debatido cuestiones como la de qué hacer con el marido que dilapidara el patrimonio familiar en el juego, en la prostitución o en otros vicios degradantes, sin llegar a ponerse de acuerdo. Mientras unos autores estimaban que de estas pérdidas respondería el marido con sus bienes propios, otros defendieron que debían gravitar sobre los gananciales, de manera que la mujer no podría evitar que mermaran su mitad. En los años inmediatos a la aparición del Código se impuso esta última solución, defendida, entre otros, por Manresa:

Así como se establece la comunión absoluta de las ganancias obtenidas en el juego [...], debe decretarse también la comunidad en las pérdidas. Y lo mismo hay que decir de lo gastado o disipado en otros vicios: de lo contrario se abrirían las puertas a escándalos e investigaciones odiosas que turbarían la paz de los vivos y mancillarían la opinión de los difuntos, aún de los inocentes ${ }^{61}$.

\section{Y así lo estableció el Código ${ }^{62}$.}

\footnotetext{
${ }^{59}$ J. M. Manresa, Comentarios al Código civil español, IX, 650; F. García Goyena, Concordancias, motivos y comentarios, art. 62: "El marido, gefe y director de la familia, administrador de todos los bienes del matrimonio y responsable de ellos, es a quien compete demandarlos o defenderlos en juicio..."; Apéndice 3 al Libro II: "En la sociedad doméstica, a la par que en todas, no puede haber sino un gefe o cabeza: esto es una necesidad; ¿y quién debía y podía serlo sino el padre? [...] El hombre, que, realmente hablando, tiene más fuerza física...".

${ }^{60}$ Leyes del Estilo 205: "Como el marido puede vender los bienes ganados durante el matrimonio.- Si alguno, seyendo casado con alguna muger, compró alguna eredad o otra cosa, que ganó estando en uno con su muger; estos bienes, que ansi compro o gano, puedelos vender el marido si menester le fuere, en tal que non lo faga el marido maliciosamente..." (= Ordenanzas Reales de Castilla, ed. Los Códigos españoles VI, Madrid, Rivadeneyra, 1849, 5.4.4; Novísima Recopilación, ed. Los Códigos españoles IX, 10.4.5).

${ }^{61}$ J. M. Manresa, Comentarios al Código civil español, IX, 613 y 646.

${ }^{62}$ Código civil, art. 59: "El marido es el administrador de los bienes de la sociedad conyugal..."; art. 1.412: "El marido es el administrador de la sociedad de gananciales..."; art. 1.413: "Además de las fa-
} 
No existe pues, freno jurídico alguno que coarte este omnímodo poder del marido en la administración de los bienes ganados en común, mientras el matrimonio persiste. Sólo cuando se haya disuelto, la mujer o sus herederos percibirán la mitad de los que en ese momento quedaran.

Por supuesto, el hombre administraba también libremente su propio patrimonio, así como los bienes que hubiera aportado a la sociedad conyugal, las llamadas arras. Y además, se le reconoció también la administración de la hacienda transferida por la mujer al matrimonio en concepto de dote, el derecho de usufructuarla y el de disponer sin límites de los frutos por ella producidos, que tienen la consideración de gananciales $^{63}$.

Con respecto a estos bienes dotales, el Código civil articuló dos regímenes diferentes $^{64}$. El primero es el de la llamada dote estimada, conforme al cual la mujer transfería el dominio sobre ellos, previamente tasados, al marido, quien quedaba obligado a restituir su valor al término del matrimonio ${ }^{65}$. Para garantizar esta obligación, debían inscribirse en el Registro de la Propiedad a nombre de él todos los bienes y derechos reales de la dote estimada, aunque gravados con una hipoteca en favor de la mujer. Una segunda hipoteca sobre las propiedades del marido aseguraba la devolución de los restantes bienes recibidos, los bienes muebles. Con estas precauciones, y con el compromiso de devolución futura, el marido incorpora a su patrimonio la dote recibida ${ }^{66}$.

En el segundo régimen, de dote inestimada, la mujer conservaba el dominio sobre ella, continuaba siendo propietaria de los bienes dotales, pero tanto la administración como el usufructo, durante el matrimonio, se atribuyeron al cónyuge ${ }^{67}$. En consecuen-

cultades que tiene el marido como administrador, podrá enajenar y obligar a título oneroso los bienes de la sociedad de gananciales sin el consentimiento de la mujer...".

${ }^{63}$ Partidas 4.11.7: "Que las donaciones, e las dotes que son fechas por razon de casamientos, deven ser en poder del marido, para guardarlas, e aliñarlas. - En possession debe meter el marido a la muger, de la donacion quel faze; e otrosi la muger al marido de la dote quel da; e como quier quel uno meta al otro en tenencia dello, todavia el marido debe ser señor, e poderoso de todo esto sobredicho, e de rescibir los frutos de todo comunalmente, tambien de lo que da la muger, como de lo que da el marido para governar a si mismo, e a su muger, e a su compañía; e para mantener e guardar el matrimonio bien, e lealmente..."; Código civil, art. 1.401: "Son bienes gananciales: [...] 33. Los frutos, rentas e intereses percibidos o devengados durante el matrimonio, procedentes de los bienes comunes o de los peculiares de cada uno de los cónyuges".

${ }^{64}$ Código civil, art. 1.346: "La dote puede ser estimada o inestimada...".

${ }^{65}$ Código civil, art. 1.346: "La dote [...] Será estimada si los bienes en que consiste se evaluaron al tiempo de su constitución, transfiriendo su dominio al marido y quedando éste obligado a restituir su importe...".

${ }^{66}$ Código civil, art. 1.349: "El marido está obligado: $1^{\mathrm{o}}$ : A inscribir a su nombre e hipotecar a favor de su mujer los bienes inmuebles y derechos reales que reciba como dote estimada u otros bastante para garantir la estimación de aquéllos. $2^{\circ}$ : Asegurar con hipoteca especial suficiente todos los demás bienes que como dote estimada se le entreguen".

${ }^{67}$ Código civil, art. 1.346: "La dote [...] Será inestimada si la mujer conserva el dominio de los bienes, háyanse o no evaluado, quedando obligado el marido a restituir los mismos bienes. Si las capitulaciones no determinaran la calidad de la dote, se considerará inestimada."; Código civil, art. 1.357: "El marido es administrador y usufructuario de los bienes que constituyan la dote inestimada...". 
cia, los inmuebles eran inscritos a nombre de la mujer, y el marido constituía hipoteca suficiente para responder de la gestión, usufructo y restitución de los muebles ${ }^{68}$.

Por último, aunque no estaba obligada a hacerlo, la mujer solía confiar a su marido casi siempre la administración de los bienes propios de ella - los llamados parafernales - bajo las garantías que hemos visto previstas en protección de la dote ${ }^{69}$. Porque si se reservaba para sí esta administración, tales bienes parafernales permanecían completamente inmovilizados, dado que ella no podía contratar, ni denunciar o resolver procesalmente los contratos ya existentes $\sin$ la previa licencia marital ${ }^{70}$, de manera que quedaba a merced del hombre para todo lo que no fuera la pasiva percepción de los frutos cuya administración, por otra parte, dada su calidad de gananciales, también correspondía a aquél ${ }^{71}$.

\section{c) La situación de la mujer viuda}

Pero la mujer no veía obscurecida su figura solamente mientras viviera a la sombra de su marido, porque el Derecho alargará esta situación todavía más allá de la muerte de aquél, razonando en ocasiones con cierta objetividad.

En primer lugar, la viuda ha venido obligada históricamente a respetar el tempus lugendi, el tiempo de llorar o tiempo de luto, por virtud del cual quedaba incapacitada para contraer nuevo matrimonio - y se le prohibía mantener relaciones sexualesdurante un cierto período de tiempo (nueve meses o diez y, finalmente un año, quizás para facilitar el cómputo) a contar desde la muerte del último marido.

Todos los ordenamientos jurídicos a partir del derecho romano consideraron que tal limitación era la mejor medida para evitar el problema de la commixtio o pertur-

\footnotetext{
${ }^{68}$ Código civil, art. 1.358: "El marido no está obligado a prestar la fianza de los usufructuarios comunes, pero sí a inscribir en el Registro, si no lo estuvieren, a nombre de la mujer y en calidad de dote inestimada, todos los bienes inmuebles y derechos reales que reciba en tal concepto, y a constituir hipoteca especial suficiente para responder de la gestión, usufructo y restitución de los bienes muebles."

${ }^{69}$ Código civil, art. 1.381: "Son parafernales los bienes que la mujer aporta al matrimonio sin incluirlos en la dote y los que adquiere después de constituida ésta, sin agregarlos a ella"; art. 1.382: "La mujer conserva el dominio de los bienes parafernales."; art. 1.384: "La mujer tendrá la administración de los bienes parafernales, a no ser que los hubiera entregado al marido ante Notario con intención de que los administre. En este caso, el marido está obligado a constituir hipoteca por el valor de los bienes que recibiere o a asegurarlos en la forma establecida para los bienes dotales".

${ }^{70}$ Leyes de Toro 55: "La muger durante el matrimonio sin licencia de su marido, como no pueda hacer contracto alguno, asimismo no se pueda apartar ni se desistir de ningun contracto que a ella toque, ni dar por quito a nadie del, ni pueda hacer quasi contracto, ni estar en juicio haciendo, nin defendiendo sin la dicha licencia de su marido: y si estuviere por si o por su procurador, mandamos que no vala lo que hiciere."; Código civil, art. 1387: "La mujer no puede, sin licencia de su marido, enajenar, gravar ni hipotecar los bienes parafernales, ni comparecer en juicio para litigar sobre ellos, a menos que sea judicialmente habilitada al efecto".

${ }^{71}$ Código civil, art. 1.385: "Los frutos de los bienes parafernales forman parte del haber de la sociedad conyugal y están sujetos al levantamiento de las cargas del matrimonio".
} 
batio sanguinis, el problema de la identificación de la paternidad de aquellos hijos que hubieran nacido en los meses inmediatos a la muerte del anterior marido y durante un segundo matrimonio. Porque en virtud de la presunción jurídica que considera que el marido de una mujer es el padre de los hijos de ésta (presunción que se prolonga después del fallecimiento de aquél para proporcionar cobertura de legitimidad a los hijos póstumos), en virtud de esta presunción, en caso de permitir la boda de una viuda nada más muerto el esposo, si ella daba a luz en los nueve o diez meses siguientes, cabía llegar a la aberrante conclusión de que, conforme a Derecho, la criatura tenía dos padres.

De modo que, neutralizadas recíprocamente las presunciones a favor de la paternidad de los dos maridos, se desembocaba en una aporía jurídica de solución irremediablemente insatisfactoria en una materia susceptible de originar perturbaciones patrimoniales de imprevisible alcance, como consecuencia de la confusión de estirpes y del consiguiente trastrueque de las líneas sucesorias.

Pero incluso en un supuesto como éste, que resulta hasta cierto punto razonable desde la objetividad de los plazos de gestación del ser humano, el Derecho se preocuparía de ensayar otros argumentos para explicar la prohibición, en una línea inequívocamente delatora del sospechoso concepto que las mujeres le merecen al legislador. Así el Liber Iudiciorum, la justificaba como precaución preventiva del aborto:

Quam idcirco mulierem praecipue huic volumus subyacere dispendio, ne haec quae a marito gravida relinquitur, dum inmoderado desiderio ad secundi coniugii vota festinat, vel adulterium perpetrans, spem partus sui, prius quam nascatur, extinguat ${ }^{72}$.

Deslizándose por la misma pendiente de desconfianza las Partidas explican así por qué hay que respetar este tiempo de luto:

Movieronse los Sabios antiguos de vedar a la muger que non casasse [o fiziesse maldad de su cuerpo] en este tiempo después de la muerte de su marido por dos razones. La primera es, porque sean los omes ciertos que el fijo que nasce della es del primer marido. La segunda es, porque non puedan sospechar contra ella porque casa tan ayna, que fue en culpa de la muerte de aquel con quien era ante casada... ${ }^{73}$.

\footnotetext{
${ }^{72}$ Liber Iudiciorum, y Fuero Juzgo, ed. Los Códigos españoles concordados y anotados I, Madrid, M. Rivadeneyra, 1847, 3.2.1; El Fuero Juzgo traduce con menos expresividad el motivo de la prohibición: "E por esto queremos que aya la muger esta pena, que aquella a quien el marido dexa prennada, quando se coyta mucho de casar, o de fazer adulterio, que non mate el parto ante que sea nazido".

${ }^{73}$ Partidas, ed. Los Códigos españoles concordados y anotados, IV, 7.6.3. La misma explicación, con variantes, en 6.3.5. Y 4.12.3, que reitera la prohibición, deja señaladas las sanciones en las que incurren las contraventoras: infamia, pérdida de las arras, de las mandas y de las donaciones otorgadas en su favor por el difunto marido.
} 
Y en el supuesto de que la viuda declarase que había quedado encinta, entraban en funcionamiento un conjunto de precauciones arbitradas para prevenir posibles fraudes por un Derecho cauteloso ante las posibles maquinaciones que cabe siempre sospechar en ellas. Así lo establecieron las Partidas:

Mugeres y ha algunas que despues que sus maridos son muertos, dizen que son preñadas dellos: e porque en los grandes heredamientos que fincan despues de muerte de los omes ricos, podria acaescer, que se trabajarian las mugeres de fazer engaño en los partos, mostrando fijos agenos, diziendo que eran suyos; porende mostraron los Sabios antiguos manera cierta, por que se puedan los omes guardar desto... ${ }^{74}$.

El Derecho español nunca llegó a superar por completo este cúmulo de prejuicios socio-jurídicos, ni siquiera bien avanzado el siglo XX, y así el Código civil declararía prohibido el matrimonio a la viuda durante los 301 días siguientes a la muerte del marido, o antes de su alumbramiento, si hubiere quedado encinta ${ }^{75}$. De vigilar la observancia de la prohibición se encargaban los Códigos penales, que tradicionalmente tipificaron este matrimonio en términos como los todavía recogidos en el Código penal de 1944: La viuda que se casare antes de los plazos establecidos por la legislación civil, incurrirá en la pena de multa de 1.000 a 5.000 Ptas., cantidades considerables en la época ${ }^{76}$.

Sin una base objetiva tan convincente como el riesgo de confusión de los linajes, que legitima el respeto del tempus lugendi en consideración a los graves trastornos jurídicos que se podían derivar de su inobservancia, concurrieron también en la viuda otras limitaciones derivadas ya abiertamente de una discriminación sexual de base sociológica que se afirma sin ningún disimulo: así, por ejemplo, el deber que gravita sobre ella, todavía en el siglo XIX, de observar una conducta honesta y de hacer vida retirada, bajo pena de perder todo lo que hubiera heredado del marido muerto e incluso su parte de los bienes gananciales, obligación de fidelidad post mortem que el Derecho nunca exigió a los viudos ${ }^{77}$.

${ }^{74}$ Partidas, ed. Los Códigos españoles concordados y anotados, IV, 6.6.17: "Que guarda deven poner los parientes del finado, quando su muger dize que es preñada del".

${ }^{75}$ Código civil, art. 45: "Está prohibido el matrimonio: [...] 2 ${ }^{\circ}$. A la viuda durante los trescientos un día siguientes a la muerte de su marido, o antes de su alumbramiento si hubiese quedado encinta..."; la Ley de reforma de 24 de abril de 1958 respetó este artículo en sus términos originales.

${ }^{76}$ Código penal de 1944, art. 475, que actualiza el importe de la pena impuesta por el de 1870, vigente al tiempo de promulgación del Código civil: "La viuda que se casare antes de los trescientos un día desde la muerte de su marido, o antes de su alumbramiento, si hubiere quedado encinta, incurrirá en las penas de arresto mayor y multa de 125 a 1.250 pesetas..." (art. 490).

${ }^{77}$ Novísima Recopilación, 10.4.5: “[...] Y otrosi mando y ordeno, que si la muger fincare viuda, y siendo viuda, viviere luxuriosamente, que pierda los bienes que hubo por razón de su mitad de los bienes que fueron ganados y mejorados por su marido y por ella, durante el matrimonio entre ellos..."; el precepto se repite en todas las Recopilaciones castellanas a partir del primer eslabón visigodo, traducido en Fuero Juzgo 5.2.5 (= Liber Iudiciorum 5.2.5 Antiqua): "Si el marido da alguna cosa a la muier, e la muier de- 
Por otra parte, la muerte del marido tampoco le abría a la mujer la posibilidad de asumir las responsabilidades que aquél afrontaba en vida con respecto a la persona de los hijos, y lo mismo cabe decir respecto de la administración de los bienes familiares.

Porque, en efecto, mientras la muerte de la madre no afecta para nada al mantenimiento de la comunidad doméstica (que sigue funcionando exactamente igual que cuando ella vivía, bajo la dirección suprema del viudo), la muerte del padre, en cambio, sí provoca la disolución del grupo familiar. En consecuencia, los huérfanos de padre debían pasar, mientras fueran menores, al cuidado del tutor o del curador testamentario -el que el propio padre hubiera designado en su testamento- apartándose a la madre de estos menesteres.

Sólo cuando el padre no hizo testamento, o cuando lo hizo, pero no señaló en él un tutor, o cuando nombró como tutora a la propia mujer, sólo en estos supuestos el juez podía encomendarle a la viuda el cuidado de sus hijos, bien entendido que no como madre, sino en calidad de tutora y, como tal, sometida a todas las cautelas propias de la institución: redacción de un inventario completo de los bienes de los hijos, establecimiento de fianza bastante para garantizar la indemnización de los hijos-pupilos en caso de inadecuada gestión, periódica dación de cuentas a los parientes paternos de los niños, etc., etc. ${ }^{78}$.

Aunque, como vemos, la tutela de la madre resulta admitida por el Derecho, Castillo de Bovadilla desaconseja recurrir a ella, porque

Algunas mugeres son tan disipadoras y perdidas en gastar, que como dizen las leyes, son de frágil consejo, $\mathrm{y}$ trabajan contra los propios provechos, y es gran culpa de los maridos, conociendo su talento, dexarlas por curadoras de sus hijos; pero por no afrentarlas publicandolas por incapaces, lo dexan a la ventura. Y muchas mugeres, debaxo del gobierno y sujeción de sus maridos tienen reprimidas y sufocadas algunas imperfecciones e impertinencias, que con la viudez y libertad se descubren, y desatan, y se abalançan a mil errores... ${ }^{79}$.

Y además, el Derecho exigía a la viuda que pretendiera ser tutora de sus hijos (por inexistencia de tutor testamentario, por encargo del marido o por decisión judicial)

pues de la muerte del marido... faze adulterio, o se casa como non deve, deve perder quantol diera el marido, e deve tornar al primer marido o a sus herederos".

${ }^{78}$ Partidas 6.16.9: "Como quando el padre, o el avuelo, non dexa guardador a sus fijos, nin a sus nietos en su testamento, lo debe aver el pariente mas propinco, que oviere.- Sin testamento muriendo algun ome, que oviesse fijos, e non les oviesse dado guardadores, o si fiziesse testamento, e non los dexasse en gaurda de ninguna [...] si los huerfanos sobredichos oviessen madre, o avuela, que quisiesse guardar los huerfanos, e sus bienes; estonze dezimos, que la madre lo puede fazer, ante que ninguno de los otros parientes, solo que sea buena muger e de recabdo. Pero debe dar, e fazer a los moços primeramente tal segurança como de suso diximos en la sesta ley ante desta. E si la madre non quisiere entremeterse desto, puede estonce el avuela aver la guarda dellos".

${ }^{79}$ J. Castillo de Bovadilla, Política para Corregidores..., III.15.32. 
el compromiso de no contraer unas segundas nupcias ${ }^{80}$. La motivación de estas exigencias dice mucho acerca de la opinión que a los mejores juristas del siglo XIII les merecían las mujeres:

E la razon, por que defendemos que non case de mientra que los moços toviere en guarda, es esta: porque podria acaescer, que por el gran amor que avria a su marido que tomasse de nuevo, non guardaria tambien las personas, nin los bienes de los moços, o faria alguna cosa, que se tornaria en gran daño dellos [...] E deve el guardador ser establescido por mandado del padre, o del avuelo; o por otorgamiento de las leyes, assi como por parentesco; o por mandamiento de los Judgadores... ${ }^{81}$.

Y en el supuesto de que se casara después de haber obtenido la tutela, quebrantando su promesa de mantener la viudez, en este caso, se encendían inmediatamente las alarmas del Derecho y entraba en juego una ley cautelar de aplicación urgente, según la cual,

[... ] luego que casare, deven sacar el huérfano de su poder, porque dixeron los Sabios que la muger suele amar tanto al nuevo marido que non tan solamente le daría los bienes de sus fijos, mas aún que consintiera en la muerte dellos por fazer plazer a su marido $^{82}$.

La doctrina interpretó lato sensu esta obligación de permanecer viuda que gravitaba sobre la madre sosteniendo que perdía también la guarda de sus hijos (aunque no se casara) por el hecho de mantener relaciones extramatrimoniales ${ }^{83}$, en extensión analógica de las normas que reservaban la tutela únicamente a la madre recatada, a la que era buena muger et de recabdo $o^{84}$, muger de buena fama ${ }^{85}$. Muy distinta era la situación del padre viudo que, como hemos dicho, conservaba la misma situación

\footnotetext{
${ }^{80}$ Partidas 6.16.4: "Quien puede ser dado por guardador de huerfanos, e de sus bienes; e por cuyo mandado.- El que fuere dado por guardador de huerfanos, non debe ser mudo, nin sordo, nin desmemoriado, nin desgastador de lo que oviere, nin de malas maneras. E debe ser mayor de veynte e cinco años; $e$ varon, e no muger. Fueras ende si fuere madre, o avuela que fuesse dada por guardador dellos. Ca estonce, tal muger como sobredicha es, si prometiere en mano del Rey, o del Juez del lugar do son los huerfanos, que demientre que los moços toviere en guarda, que non casara [...] estonce bien le puede otorgar la guarda de sus fijos, o de sus nietos...".

${ }^{81}$ Partidas 6.16.4.

${ }^{82}$ Partidas 6.16.19. La preocupación del legislador se manifiesta en la reiteración: que la madre bínuba perdía la guarda de su hijo estaba ya establecida en 6.16.5: "Como la madre non puede aver sus fijos en guarda, si se casare despues de la muerte del padre dellos. - Casando la madre de mientra que sus fijos tuviesse en guarda [...] el Juez del lugar do acaesciere, debe sacar los moços luego de su guarda, e de su poder, e darlos a alguno de sus parientes...".

${ }^{83}$ Partidas 6.16.5, glosa Casando.

${ }^{84}$ Partidas 6.16.9.

${ }^{85}$ Partidas 6.16.19.
} 
que había tenido en vida de su mujer, es decir, continuaba asumiendo no la tutela, sino la patria potestad con todos sus poderes, aunque volviera a casarse y con independencia de cuál fuera su conducta.

La patria potestad no se le reconocería a la madre viuda hasta la promulgación del Código civil, que vino a satisfacer así lo que era ya un unánime clamor reivindicativo de la doctrina:

¿Por qué la madre no participa de ese honor [se preguntaba otro de los redactores de nuestro Código civil], honor que tiene por naturaleza con más derecho que el padre? Durante el matrimonio no es tan preciso concedérsela: con que tenga la intervención propia de su estado, logre hacerse escuchar, e influya, como no puede menos, con su consejo, basta. Libre de otra responsabilidad, queda más espedita para los quehaceres domésticos, y declina sobre su marido el peso de otras preocupaciones.

Pero, ¿qué derecho hay para alejarla, postergándola quizás a un extraño el día que sea viuda? ¿tienen las madres menos cariño que los padres por sus hijos? ¿y este sentimiento esquisito de ternura maternal no suplirá poderosamente alguna corta inferioridad en conocimientos? Si la madre no puede estar constituida al nivel del padre por la impresionabilidad del sexo, su cariño es gran preservativo contra sus debilidades y la pone, si no a la altura de un padre, a más distancia de un estraño. Sería conveniente recordar nuestras antiguas leyes, desgraciadamente olvidadas, para convencernos del contrasentido de las vigentes en un país que llama a las hembras a la plenitud de la soberanía, y que cuenta entre sus reinas a Doña Berenguela, doña María de Molina y a la inmortal doña Isabel la Católica ${ }^{86}$.

No obstante abundar los razonamientos de este tipo, algo sobrevivió de la vieja suspicacia con que el Derecho contemplaba el segundo matrimonio de la mujer, porque el Código la privó de la patria potestad, como antes se la privaba de la tutela, en el caso de que pasase a segundas nupcias ${ }^{87}$, aunque precisando que, si volviere a en-

${ }^{86}$ B. Gutiérrez, Códigos o Leyes fundamentales sobre el derecho civil español, I. 591 y 775, siguiendo con cita literal a F. García Goyena, Concordancias, motivos y comentarios, Apéndice 3 al Libro II: “[... ] Se objeta a las mugeres su debilidad e inesperiencia; se dice que todas las legislaciones han reconocido al padre por gefe de la comunidad doméstica, y con esto su superioridad sobre la muger; que nadie conoce mejor que él mismo el estado de su familia y la actitud moral e intelectual de su muger [...] Contra la debilidad, inesperiencia e incapacidad del sexo, diré yo, que más de una vez no le encontramos tan débil como querríamos, y como nosotros mismos lo somos; que las facultades intelectuales son iguales en ambos sexos, y por lo común el primer golpe de vista de las mugeres es más fino, más penetrante y seguro [...] que si en efecto resultara incapacidad o inesperiencia de parte de la muger, sería ordinariamente culpa del marido, que no le habría dado en el gobierno y negocios de la familia toda la participación debida; que el amor materno es más vivo e ingenioso [...], que las mugeres son más económicas; y según la espresión de nuestras leyes mas avariciosas y codiciosas. Señores, aquí no se trata sino del cuidado de los hijos y de la administración de sus bienes, no de negocios públicos; y hasta en política se ha observado que los reinados de las hembras han sido más felices...”.

${ }^{87}$ Código civil, art. 168: "La madre que pase a segundas nupcias pierde la patria potestad sobre sus hijos, a no ser que el marido difunto, padre de éstos, hubiera previsto expresamente en su testamento que su 
viudar, recobraría desde ese momento mismo la patria potestad sobre todos los hijos no emancipados ${ }^{88}$.

\section{El derecho penal}

En contraste con las sensibles restricciones impuestas por el derecho civil a la capacidad de obrar de la mujer, en el ámbito del derecho penal el distinto tratamiento de que fueron objeto hombres y mujeres se tradujo a veces en ventajas concretas para éstas, aunque, como vamos a ver, también abunden las limitaciones.

\section{a) Ventajas y desventajas de la imbecillitas seu fragilitas sexus}

En principio, la mujer se benefició penalmente de esa debilidad moral y física que el Derecho le atribuía con relación a los hombres y recibió un tratamiento indulgente que aproximaba su conducta a la de los niños y a la de los débiles mentales. Como ellos, las mujeres podían disculpar algunos de sus comportamientos antijurídicos, al menos en parte, con la excusa de haber obrado bajo los efectos del miedo o de la coacción, aunque fueran leves; $y$, en virtud de su pretendida imbecillitas, quedaron exentas de la obligación general de conocer las leyes, de manera que en ellas se admitía, con mucha más facilidad que en los varones, la atenuante de ignorancia.

Resultó también aceptada, con general beneplácito, la regla de que las mujeres no debían ser castigadas con el mismo rigor que los hombres, por lo cual, atendiendo a su menor resistencia a las privaciones y al dolor físico, los juristas aconsejaron que se atenuara con ellas la dureza de las penas ordinarias. Y, en efecto, quedaron exentas de penas como la de galeras, que se les conmutaba por la de destierro, para que su pudor no sufriera deterioro en medio de la promiscua convivencia con la chusma. No llegaron, en cambio, a librarse de la pena de los azotes, aunque éstos se administraban casi siempre conforme a una liturgia especial encaminada a no herir la decencia de los espectadores y la de las propias condenadas con la inoportuna exhibición de sus carnes pecadoras. Por fin, tanto la legislación como la literatura jurídica insistieron en que ni la pena de muerte, ni ninguna otra pena corporal, ni tampoco trámites procesales agresivos, como el tormento, debían ejecutarse sobre las mujeres embarazadas ${ }^{89}$.

Pero junto a estas consecuencias ventajosas del sexo, abundaron también en el derecho penal supuestos en los que la discriminación jurídica conducía a resultados ne-

viuda contrajera matrimonio y ordenado que en tal caso conservase y ejerciese la patria potestad sobre sus hijos"; La ley de 24 de abril de 1958 le permitiría ya conservarla.

${ }^{88}$ Código civil, art 172: "Si la madre viuda que ha pasado a segundas nupcias vuelve a enviudar, recobrará desde este momento su potestad sobre todos los hijos no emancipados".

${ }^{89}$ Partidas 7.31.11; A. Gómez, Variae resolutiones Juris civilis, communis et regii, Lugduni, 1701, III, 13, 3, "Mulier praegnans nec torqueri nec terreri potest "; J. Clarus, Opera Omnia, Frankofurti, 1582, V, q. 64, no 23: "Quaero modo, nunquid mulier praegnana possit torqueri?". 
gativos. Hubo, por ejemplo, delitos de exclusiva comisión por las mujeres, como el de prostitución, cuyo ejercicio acarreaba, además de las correspondientes penas, un juicio social de reproche que se refleja, por citar sólo un ejemplo, en el hecho de que agresiones como el estupro, los abusos sexuales o la violación, sólo alcanzaban consideración de delito cuando la víctima fuera una mujer honrada, de manera que las prostitutas quedaron jurídicamente desprotegidas ante ataques de esta naturaleza. Una desprotección que la jurisprudencia de los tribunales españoles ha mantenido hasta bien entrado el siglo $\mathrm{XX}^{90}$.

Y, sin embargo del tratamiento humillante y despectivo que el derecho penal histórico les ha dispensado, las prostitutas disfrutaron, al menos en el imaginario popular, de un privilegio que, paradójicamente, sólo estaba reconocido, además de a ellas, a los Reyes, a los Papas, y a los Emperadores: el de poder indultar a cualquier condenado a muerte en el trance mismo de la ejecución. Para ello, no tenían más que subir al tablado y arrancarlo de las manos del verdugo, prometiendo públicamente casarse con él. Apostillada por algún tratadista con curialesco y espeso sentido del humor (apuntando que bien se conoce aquí que el matrimonio es un suplicio mucho más temible que la muerte), la jurisprudencia más solvente vino a desmentir esta supuesta facultad ${ }^{91}$, lo que no alcanzó a deshacer una leyenda cuya popularidad encontró reflejo en expresiones que el ingenio del pueblo elevó a la categoría de frases hechas:

Dadle al asno se aplica al que, yendo a vistas, le ha parecido fea la novia y quiere más pasar su trabajo que casar con un monstruo. Tuvo origen de que, llevando a

\footnotetext{
${ }^{90}$ Partidas 7. 20. 1 y 3 requiere, para que el rapto o la violación de una mujer casada, soltera o viuda sea punible, que la víctima "biva honestamente en su casa", o sea "de buena fama"; así lo entendió también la doctrina, por ejemplo, A. Gómez, Ad leges Tauri commentarium absolutissimum, Lugduni, 1761, comm. in Legem $L X X X, \mathrm{n}^{\circ}$ 45: "Advertendum tamen est, quod superiora habent locum et procedunt in virgine, vidua, vel honesta muliere; secus tamen est in publica meretrice, quia si quis eam rapiat vel per vim carnaliter eam cognoscat, non punitur aliqua poena [...]". Todavía los Códigos penales españoles mantuvieron rastros de esta discriminación: el Código penal de 1822 reduce a la mitad las penas correspondientes al rapto, a la violación y a los abusos deshonestos cuando la víctima fuere "una muger pública" (art. 670), el de 1928, castigaba la violación de una mujer con pena de tres a doce años de prisión (art. 598), rebajada de uno a tres cuando la violada se dedicase habitualmente a la prostitución (art. 600), y el de 1944, exigía "acreditada honestidad" en la menor de veintitrés para castigar al patrono o jefe que, prevalido de esta condición, hubiera tenido acceso carnal con ella (art. 437).

${ }^{91}$ J. Castillo de Bovadilla, Política para Corregidores, III.15,142: “Assi mismo suele dudarse si al condenado a muerte, que llevan a justiciar, le pidiesse por marido una ramera pública, e el lo acetasse, si se libraria: en lo qual afirma Paris de Puteo praticarse en España que si. Y lo mismo dicen Cassaneo y Paponio de Francia. Y lo mismo tienen otros Doctores. Pero lo contrario es mas recebido, y no he visto que se dexe por edto de executar la justicia de muerte”. A. Gómez, Variae resolutiones..., III. 13. 37 , casus 5: "[...] Quintus casus est, quando reus condemnatus velit accipere in uxorem aliquam meretricem existentem in lupanari, quia per hoc videtur sibi remittenda poena [...] et aliquando fuit ita practicatum in isto regno [...] El quaesivi a peritis judicibus, qui idem mihi dixerunt. Sed iste casus non est verus nec tenendus, quia non reperitur jure cautum. Itam quia tenderet in grave praejudicium reipublicae, quia viles, ribaldi et infames quotidie delinquerent, sperantes veniam ducendo meretrices in uxores...”.
} 
ahorcar un mozo de buen talle, salió una mujer de la casa pública, diciendo que le pedía por marido. Paráronse todos muy alegres, pensando le librarían de la horca. Llegó la mujer y, como el la vido tan fea y abominable, volvióse al verdugo y dijo: -Dadle al asno ${ }^{92}$.

Pero, por debajo de las motivaciones religiosas y demográficas que pueden explicarlo, el fabuloso privilegio encierra un cierto toque de extravagancia que es buen exponente de la carga de arbitrariedad que, en mayor o menor medida, a lo largo de la historia, la materia jurídica ha llevado siempre dentro de sí.

\section{b) La discriminación en el adulterio}

Hubo también delitos cuya gravedad aumentaba cuando eran cometidos por una mujer, por ejemplo, el de blasfemia, o el de embriaguez, que desdecían del decoro propio del sexo o, como el adulterio, en cuya represión se advierte, mejor que en ningún otro, el alcance penal de la discriminación sexual.

Porque para el ordenamiento jurídico, desde siempre y hasta fechas muy cercanas a nosotros, el adulterio del hombre casado sólo se ha apreciado cuando la relación extramatrimonial temía carácter permanente, es decir, cuando el hombre mantuviera a su cómplice, a su manceba, dentro de la casa familiar, o cuando conviviese con ella públicamente; los dos supuestos quedaron castigados con penas económicas que en el siglo XVII, según la Nueva Recopilación de Felipe II, podían llegar, en los casos más graves, hasta la confiscación de la mitad de los bienes del adúltero ${ }^{93}$.

Y sin embargo, la mujer cometía adulterio siempre que realizara un acto sexual, aunque fuera único y episódico, con cualquier hombre que no fuera su marido. Legisladores y juristas se pertrecharon de nuevo con argumentos de tipo biológico para defender esta diferencia de tratamiento, fundándola en el riesgo de que se produjera un eventual embarazo de la mujer como consecuencia de esa relación ilícita, lo que podría originar fraudes sucesorios, puesto que el Derecho atribuirá al marido de la adúltera la paternidad del niño. Otra vez aparece así la commixtio sanguinis para justificar una discriminación que aquí tiene la finalidad complementaria de proteger la honra conyugal desde esa concepción que suele denominarse calderoniana y que, como era inevitable, va a resolverse también en términos profundamente desventajosos para la mujer.

Porque, efectivamente, desde el derecho romano quedó afianzado el principio de que el marido puede matar impunemente a los adúlteros cuando los hubiera sorprendido in fraganti, facultad que proclaman expresamente todos los derechos históricos de Occidente. A falta de la evidencia proporcionada por el delito flagrante, el marido

\footnotetext{
${ }^{92}$ S. de Covarrubias, Tesoro de la Lengua Castellana o Española, ed. Turner, Madrid 1979, 158.

${ }^{93}$ Sobre el adulterio del hombre casado vid, E. Gacto, "La filiación ilegitima en la historia del Derecho español”, Anuario de Historia del Derecho español, 61 (1971), 921 y ss.
} 
podía optar también por acusarlos ante la justicia, siempre que tuviera pruebas suficientes, y en este caso, si quedaban judicialmente convictos, la mujer y su cómplice sufrían la vergüenza de recorrer desnudos las calles de la ciudad, bajo el azote del verdugo, eran desterrados o se les imponía la pena capital, abriéndose un amplio abanico de posibilidades en cuanto a la forma de ejecución: en España, donde apenas se practicaron castigos que eran usuales en otros países de Europa como la lapidación, el rebanamiento de la nariz o la muerte por ahogamiento en un estanque, en España la adúltera era casi siempre degollada, y otras veces conducida a la hoguera, ahorcada o entregada al marido junto con su cómplice, para que hiciera con ellos lo que quisiese ${ }^{94}$.

Desde principios de la Edad Moderna, la doctrina penal española reseña como muy difundida la costumbre de que el verdugo invitara al marido burlado a subir a la plataforma del cadalso donde le cedía los trastos de matar, para que fuera él quien ejecutara la sentencia de propia mano, como habría hecho si hubiera podido descubrir a los adúlteros en el mismo trance de la consumación de su delito.

Sobre la práctica de este ritual, generalizado en España desde la Edad Media, abundan testimonios ridiculizantes como el contenido en la carta que el franciscano Fr. Juan de Mendoza remitió a Quevedo:

Un maestro sastre catalán, de nombre Cosme Sevaro estaba casado con Manuela Tablantes, la que mantenía relaciones criminales con José Márquez, que trabajava en calidad de oficial en la sastrería de Cosme en el pozo de los traperos [...] Quando el oficial tenía el antojo de ver a Manuela dezía: Seda, señora maestra, y ella respondía: suba por ella, y desto quedó un refrán que agora se dize en todas las plaças de Sevilla [...] El veinte y dos de octubre recayó sentencia mandando que se entregasen al querellante ambos reos para que hiciese de ellos lo que quisiere sin poder matar al uno y dejar al otro. El mesmo dia fue hecho, a petición del marido, un cadahalso en medio de la plaça de San Francisco [...] Llegó el viernes [...] y se despejó la plaça para dejar paso a los ajusticiados que venían de la cárcel real. Salieron della a las once sobre dos borricos: delante la muger vestida toda de negro, traía la estampa de la Virgen de la Macarena entre su pecho encerrada y rezaba una salve; el mozo de blanco, cabizbajo y con un cristo en su mano. Ivan rodeados de religiosos [...] los condujeron directos a la plaça y los subieron al cadahalso colocando a la muger de rodillas con el rostro hacia la Audiencia, y al mozo mirando hazia la parte opuesta. La Audiencia ordenó que se trajese a Cosme. A la sazón, y según lo acordado, salimos del convento de San Francisco veinte frailes y nos dirigimos al tablado. Sorteando como bien pudimos la pólvora que lanzavan los soldados con sus arcabuces cruzamos la plaça. Depositamos nuestra devotísima imagen del Santo Cristo en la escalera por la que Cosme havía de suvir para consumir la vengança, postrándonos ante el marido, rogándole y persuadiéndole para que otorgase a los criminales perdón. Furioso nos pedía que le dixeramos quién le restauraría su honra y nosotros le recordábamos sin fortuna las palabras de Jesús en su encuentro con una adúltera. Seguimos porfiando

\footnotetext{
${ }^{94}$ Ibidem, 907 y ss.
} 
sobre el asunto hasta que él llegó hasta donde su muger se hallaba. Manuela se echó a sus pies y entre lágrimas suplicava perdón de las graves ofensas que havía hecho. Él le dava con el pie y se desasía della. La gente empezó a protestar del marido porque la muger era hermosa y no gustavan verla con las bozes que dava. Así se sucedió una hora hasta que, viéndose que no se le ablandava el corazón, resolvimos que quatro de nosotros abrazaran al marido mientras otros clamavan: ¡ya ha perdonado! entre las muestras de júbilo del gentío. Cosme se agitaba esforzándose en señalar que no era verdad lo que se dezía, y de este modo alzando la mano, pataleando prosiguió hasta que el bullicio allí congregado lo echó abajo y medio muerto lo llevaron a San Francisco, en donde no cesó de llorar [...] Amigo mío, si un día viene a Sevilla [...] habrá de escuchar la copla que los mancebos cantan para memorial de la muger hermosa y pecadora y aflicción del pobre cornudo que tuvo a bien tomarla como esposa: Todos le ruegan a Cosme, que perdone a su muger; y él responde con el dedo; señores, no puede ser. ${ }^{95}$

Y hay que decir también que una regulación como ésta, que hoy puede parecernos desmesurada, recibió sin embargo en su día la crítica social por todo lo contrario, por entender que resultaba demasiado benévola, demasiado formalista. Para el sentir colectivo de los españoles, desde época medieval, en este tipo de asuntos relacionados con la honra sobraban muchas de las garantías exigidas por el Derecho. Para este sentir colectivo, el hombre honrado debía defender su honor prescindiendo de requisitos probatorios inventados por leguleyos, que no servían más que para favorecer las malas artes de las mujeres.

Nuestra literatura clásica ha sabido reflejar muy bien esta mentalidad. En otro lugar he analizado de qué forma abordó la cuestión Alonso Martínez de Toledo, hacia la mitad del siglo XV, en una fábula en la que la sagacidad del hombre triunfa sobre la proverbial malicia mujeril que, según vimos ya, Sánchez de Vercial había subrayado años antes. El Arcipreste nos presenta a un marido engañado que es demasiado cobarde para matar a los adúlteros por su propia mano y que tampoco quiere airear su deshonra acudiendo a los tribunales, desanimado además al pasar revista a la complicada serie de formalidades que debería tramitar para que su denuncia prosperase. De manera que idea una combinación que va a convertir a la adúltera, víctima de su propia picardía, en ejecutora de sí misma ${ }^{96}$.

${ }^{95}$ Relación verdadera de lo que ha sucedido en este año de mil y seiscientos y veinte y quatro... en la ciudad de Sevilla a un marido que, aviendo sido ultrajado por su muger adúltera, es auxiliado por la justicia y condenados muger y amante a morir degollados por mano de su marido... carta que embió el padre de la orden de San Francisco a don Francisco de Quevedo y Villegas, caballero de la Orden de Santiago y Señor de la Torre de Juan Abad, con licencia, Impresso en Sevilla, año de 1624.

${ }^{96}$ E. Gacto, "El Derecho y la Justicia en las fuentes literarias", en Anuario de Historia del Derecho Español, 77 (2008), 509-555; A. Martínez de Toledo, Arcipreste de Talavera o Corbacho. Ed. J. González Muela. Clásicos Castalia, Madrid 1970, 2.7: "El buen hombre sintió su mal, e sabiamente usando, mejor que algunos que dan luego de la cabeça a la pared, dexó pasar un día, e dies, e veinte, e pensó cómo daría remedio al dicho mal. E pensó acabar con ella por una vía que él sin culpa fuere ante el mundo, 
El relato transmite al lector una subliminal propuesta de identificación con el marido, se complace en deslizar la sugerencia apenas insinuada pero complaciente de que su conducta merece aprobación, porque el mejor modo de desenredar la enmarañada madeja gordiana de la justicia es cortándola de un tajo. Basta con un poco de sentido común —nos viene a decir- y con un mínimo conocimiento de las intemperancias que anidan en el alma de la mujer desde tiempos de nuestra madre Eva, para que sus maldades puedan ser castigadas como se merecen prescindiendo de las garantías de un Derecho excesivamente benigno y contemporizador con sus defectos.

La tradición española que vincula el adulterio femenino con la honra del marido serpentea por el teatro de Lope, de Tirso de Molina o de Andrés de Claramonte, y alcanza calidad de paradigma en obras de Calderón (El Tetrarca, El médico de su honra, El pintor de su deshonra o A secreto agravio, secreta venganza), dramas en los que los maridos, sean nobles o villanos, entienden esto del adulterio como un asunto privado que es preciso resolver de manera reservada, al margen de la justicia, de forma clandestina si hace falta, pero siempre sangrienta. Y lo hacen sin ningún titubeo, a sabiendas de que esa es la única forma socialmente aceptable (ante los hombres y tal vez ante la propia conciencia) de lavar el deshonor conyugal.

Incluso cuando esta mentalidad desembocaba en terribles equivocaciones su validez nunca fue puesta en entredicho. En El médico de su honra, por ejemplo, don Gutierre, convencido del adulterio de su mujer, hace que un barbero le aplique a ésta una sangría suelta para que su muerte parezca accidental. Cuando el equívoco se deshace y la inocencia de doña Mencía queda manifiesta, el rey don Pedro puntualiza que el marido ha obrado como un hombre de honor, como debe hacerlo un caballero, y lo recompensa con la mano de doña Leonor, de la que había estado enamorado en su juventud.

de manera que paresciera ella ser de su propia muerte causa. E así, tomó ponsoñas confacionadas e mesclólas con el mejor e más odorífero vino que pudo aver, porque a ella non le amargaba el buen vino, e púsolo en una ampolla de vidrio, e dixo: "- Si yo aquesta ampolla pongo donde ella la vea, aunque yo le mande: "cata que non gustés desto", ella, como es muger, lo que yo le vedare aquello mesmo hará, e non dexará de beber dello, e assí morirá”. Dicho e fecho. El buen hombre sabio tomó la ampolla e púsola en una ventana donde ella la viesse. E luego dixo ella: "— ¿Qué ponés ahí, marido? Respondió él: “Muger, aquesta ampolla. Pero mándote e ruego que non gustes de lo que dentro tiene, que si lo gustas, luego morirás, así como Nuestro Señor dixo a Eva. E esto, lo dixo en presencia de todos los de su casa, porque fuessen testigos. E luego fizo que se iba, e aún no llegó a la puerta cuando ella, luego tomó la ampolla, e dixo: "- Quemada me vean si yo non veo qué es esto. E olió la ampolla, e vió que era vino muy fino, e dixo: “- Ah, qué marido, y qué descortés. ¿Desto dixo que non gustase yo? Pascua mala me de Dios si non lo pruebo. Non plega a Dios que él sólo se lo beba. Que las buenas cosas non son todas para boca de rey. Dió con ella a la boca, e bebió un poco, e luego cayó muerta. Desquel marido sintió las voses dixo: “- Dentro yase la matrona. Luego entró corriendo, mesándose las barbas, diciendo a altas voses: "—A, mesquino de mí — pero baxo desía: "Bien muerta está la traidora" — En altas voses desía: “Captivo! ¿Qué será de mí? E, en su corasón: "Ya te acabé menguada”; es una traslación del exemplum XIV (De puteo) de la Disciplina clericalis. 
Que tales situaciones no se daban sólo en el ámbito de la ficción lo demuestra la noticia de Pellicer a propósito de la muerte de la mujer de Alonso Cano, un caso en el que esta forma de pensar orienta a la justicia automáticamente hacia el marido:

Sucedió cuatro días ha que Alonso Cano, pintor de gran fama, tenia un pobre que acudía a su casa para copiar dél los cuerpos que pintaba. Y, estando él fuera de casa y su mujer en la cama sangrada, el pobre se quedó cerrado en el obrador y, saliendo al aposento de la mujer, la mató con quince puñaladas con un cuchillo pequeño. Escapóse, y a ella la hallaron con matas de los cabellos del pobre en la mano. Vino su marido y, por los indicios de disgustos que tenía con ella sobre mocedades suyas, le prendieron y han dado tormento. Negó en él haberla hecho matar. Y hase recibido la causa a prueba, y se cree está sin culpa ${ }^{97}$.

Visiones como éstas, que pueden parecernos hoy lejanas y poco menos que exóticas o anacrónicas, han persistido, sin embargo, prácticamente hasta ayer, como un reflejo de esa filosofía patriarcal de que hablaba al principio y que, se reconoce todavía en los Códigos modernos, que nos siguen mostrando la misma panorámica levemente amortiguada con ligeras atenuaciones.

El Código civil español, por ejemplo, prolongó con palabras modernas la definición medieval del adulterio. Al enumerar las causas legítimas de separación, el Código se expresaba así: Son causas legítimas de separación: $1^{\circ}$. El adulterio de la mujer en todo caso, y el del marido cuando resulte escándalo público o menosprecio de la mujer $^{98}$. De manera que seguimos instalados todavía, a finales ya del siglo XIX, dentro de los mismos esquemas mentales de la Edad Media: el marido puede pedir la separación por el adulterio de la mujer en todo caso, es decir, siempre, incluso por un solo acto aislado de infidelidad; la mujer en cambio, sólo podrá alegarlo cuando el adulterio del marido provoque escándalo público (esto es, en el caso de que conviva con otra mujer de forma permanente, con pública notoriedad) o cuando implique menosprecio de la esposa, o sea, cuando el marido haya instalado dentro de su propia casa a la mujer con la que convive maritalmente.

En cierto modo, rastros de la vieja concepción medieval se cobijaron también en los Códigos penales que, además de mostrarse reticentes a la hora de calificar como adulterio las relaciones extramatrimoniales del marido, las tipificaron restrictivamente $^{99}$. Y que sancionaron a la mujer casada que las mantuviera, consagrando el tradicional principio de desigualdad en la materia, con penas bastante más severas que

\footnotetext{
${ }^{97}$ J. Pellicer de Tovar, Avisos, ed. J-C.Chevalier, París 2002, I, “Avisos de 14 de junio de 1644”.

${ }^{98}$ Código civil, art. 105.

${ }^{99}$ El concepto de adulterio que formulan los Códigos penales inspiró el aceptado por el Código civil que acabamos de ver: Código penal de 1822, arts. 684 y 685; Código penal de 1848, arts. 349 y 353; Código penal de 1850, arts. 358 y 362; Código penal de 1870, arts. 448 y 452; Código penal de 1928, arts. 621 y 622; Código penal de 1944, arts. 449 y 452.
} 
las previstas para los varones, cuya aplicación quedaba también —como en siglos atrás- a merced de la voluntad del marido ${ }^{100}$.

Por otra parte, hasta la segunda mitad del siglo XX, todos los Códigos penales españoles han tipificado el denominado por la doctrina uxoricidio honoris causa, una versión mitigada del viejo derecho que asistía al marido para matar a los adúlteros cuando los sorprendía in fraganti porque, si bien ahora ya se castiga al matador, la pena que se le impone es casi irrisoria. El Código penal de 1944 lo recoge todavía en estos términos:

El marido que, sorprendiendo en adulterio a su mujer, matare en el acto a los adúlteros o a alguno de ellos, o les causare cualesquiera lesiones graves, será castigado con la pena de destierro. Si les produjere lesiones de otra clase, quedará exento de pena. Estas reglas son aplicables, en análogas circunstancias, a los padres (respecto de sus hijas menores de veintitrés años y sus corruptores) mientras aquéllas vivieren en la casa paterna. ${ }^{101}$

Impunidad total, por tanto, para el marido que produce lesiones menos graves a los adúlteros; si comete con ellos un doble homicidio o un doble asesinato, pena de destierro, que según el propio Código, consiste en la prohibición de aproximarse a la localidad de los hechos en un radio de entre 25 y $250 \mathrm{kms} .{ }^{102}$ durante un período que podía oscilar entre seis meses y seis años ${ }^{103}$ : una pena puramente simbólica si la comparamos con la que correspondía imponer a la mujer por la misma conducta. Porque si la mujer, sorprendiendo en adulterio a su marido, lo matara, sería condenada como parricida a la pena de reclusión mayor a muerte ${ }^{104}$, entre 20 y 30 años de cárcel en el supuesto de que pudiera eludir la pena capital ${ }^{105}$. En el caso de matar a la mujer que estuviera con él, la pena era la misma, reclusión mayor a muerte por delito de asesinato ${ }^{106}$, aunque en el mejor de los casos, si el tribunal la consideraba culpable sólo de homicidio simple, sería condenada a pena de reclusión menor ${ }^{107}$, de 12 a 20 años de cárcel ${ }^{108}$.

${ }^{100}$ Código penal de 1822, arts. 683 y 685; Código penal de 1848, arts. 349, 351 y 353; Código penal de 1850, arts. 358, 360 y 362; Código penal de 1870, arts. 448 y 452; Código penal de 1928, art. 620 iguala ya las sanciones, aunque mantiene la discriminación de las conductas; Código penal de 1944, art. 449 y art. 452 establece también una regulación paritaria de las penas, pero emplea el término "adulterio" sólo para referirse a la conducta de la mujer casada.

${ }^{101}$ Código penal de 1944, art. 428. Con variantes de detalle, el artículo vino a prolongar una regulación mantenida en los Códigos anteriores: Código penal de 1822, art. 619; Código penal de 1848, art. 339; Código penal de 1850, art. 348; Código penal de 1870, art. 438; Código penal de 1928, art. 523. Sólo desparece en el Código penal de 1932, despenalizador del adulterio.

${ }^{102}$ Código penal de 1944, art. 88.

${ }^{103}$ Código penal de 1944, art. 30.

${ }^{104}$ Código penal de 1944, art. 405.

${ }^{105}$ Código penal de 1944, art. 78.

106 Código penal de 1944, art. 406.

107 Código penal de 1944, art. 407.

${ }^{108}$ Código penal de 1944, art. 78. 
Un mismo hecho (la muerte de los adúlteros) podía castigarse, pues, con destierro de seis meses si lo hubiera cometido un hombre. $\mathrm{O}$ con dos penas de reclusión mayor a muerte cuando la autora fuese una mujer, a la que no alcanzaban los beneficios del conyugicidio honoris causa.

Discurriendo sobre semejante anacronismo, un penalista español de reconocida solvencia escribió hace unos años que este artículo del Código penal de 1944 no sólo carecía de todo efecto intimidatorio, sino que realmente entrañaba una auténtica invitación para eliminar a dos seres humanos. En materia de relaciones sexuales -escribe- el legislador penal tiene ideas bastante confusas, pero hay un punto en el que tiene absoluta claridad de visión: "[...] con la madre, con la esposa y con la hija no se pueden gastar bromas. Y como su madre no suele estar ya en edad de despertar pasiones, al legislador únicamente le preocupan la esposa y la hija. Con ellas no se admite que nadie gaste bromas. Y mucho menos aún que sean ellas las que las gasten"109.

Este translaticio y pintoresco artículo de los Códigos penales españoles se mantuvo vigente todavía hasta su desaparición en $1963,{ }^{110}$ aunque hay que señalar que en ella iba encerrada una notable dosis de hipocresía jurídica. Porque, aunque fue derogado, el legislador se preocupó de dejar muy claro que el horizonte ideológico apenas había experimentado variaciones.

En efecto, la Ley de Bases de 1961 que ordenaba su supresión no alega como fundamento de ésta su carácter inhumano, o su falta de racionalidad o el evidente agravio comparativo hacia la mujer. El artículo debe suprimirse, afirma, ya que la finalidad que se propone en este precepto se logra a través del juego de los principios generales de las eximentes primera y cuarta del artículo octavo, o de las atenuantes quinta, sexta y octava del artículo noveno ${ }^{111}$; es decir, desaparece porque resulta superfluo, puesto que la exculpación del marido homicida queda suficientemente garantizada a través del juego de las eximentes o atenuantes, que deben apreciarse siempre en semejante situación. Así que, suprimido el artículo, la jurisprudencia pudo mantener por largo tiempo el trato preferente del marido que mata a la mujer y al amante de ésta, recurriendo a las eximentes de trastorno mental transitorio, de legítima defensa o a las atenuantes de provocación, vindicación de una ofensa grave o arrebato ${ }^{112}$.

${ }^{109}$ E. Gimbernat Ordeig, "La mujer y el Código penal español”, Cuadernos para el diálogo, $\mathrm{n}^{\circ}$ extraordinario XXVIII, "Delito y Sociedad", diciembre 1971, 19.

${ }^{110}$ Decreto de 24 de enero de 1963 (BOE de 2 de febrero), 1, d): "Se llevan a cabo en el libro segundo del Código Penal las alteraciones de sistema que se indican: el artículo cuatrocientos veintiocho, de contenido nuevo...".

${ }^{111}$ Ley de 23 de diciembre de 1961 (BOE de 27 de diciembre), 1, base octava; la consideración 2a del Preámbulo justifica la medida "en gracia al juego de las eximentes primera..." etc.

${ }^{112}$ Código penal de 1944, art. 8: "Están exentos de responsabilidad criminal: $1^{\circ}$. El enajenado y el que se halla en situación de trastorno mental transitorio [...] $4^{\circ}$. El que obra en defensa de su persona o derechos, siempre que concurran las circunstancias siguientes: Primera. Agresión ilegítima [...] en caso de defensa de la morada o sus dependencias se reputará agresión ilegítima la entrada indebida en aquélla o éstas durante la noche o cuando radiquen en lugar solitario."; 9: "Son circunstancias atenuantes: [...] 


\section{Hacia la igualdad}

Aparte de supervivencias anacrónicas tan llamativas como ésta del uxoricidio, en ámbitos jurídicos menos espectaculares (como el familiar, el de la contratación, el laboral o el administrativo) la discriminación de la mujer se mantendrá en vigor hasta bien avanzado el siglo XX, lastrando el racionalismo de unos Códigos que aspiraban a implantar el imperio de la lógica jurídica en el mundo del Derecho. Por ello habrá que esperar también aquí hasta fechas relativamente recientes para que la igualdad entre los sexos, cada vez menos discutida en el nivel teórico, comience a llenarse de contenido.

Así, en la esfera del derecho público, la primera declaración de igualdad política entre hombres y mujeres no se registra hasta la Constitución de 1931, que permite por primera vez en la historia de España el voto femenino ${ }^{113}$. Y aunque en 1918 había quedado reconocida la capacidad de la mujer para optar a los empleos públicos ${ }^{114}$,

$5^{\mathrm{a}}$. La de haber precedido inmediatamente provocación o amenaza adecuada de parte del ofendido. $6^{\mathrm{a}}$. La de haber ejecutado el hecho en vindicación próxima de una ofensa grave causada al autor del delito[... ] 8a . La de obrar por estímulos tan poderosos que, naturalmente, hayan producido arrebato u obcecación". ${ }^{113}$ Constitución española de 1931, art.36: "Los ciudadanos de uno y de otro sexo, mayores de veintitrés años, tendrán los mismos derechos electorales conforme determinen las leyes".

${ }^{114}$ Ley de 22 de julio de 1918 (BOE de 24 de julio): "Base 2a. Ingreso. La mujer podrá servir al Estado en todas las clases de la categoría de Auxiliar. En cuanto a su ingreso en el servicio técnico, los Reglamentos determinarán las funciones a que puede ser admitida y aquéllas que por su especial índole no se le permitan. Su ingreso se verificará siempre previos los mismos requisitos de aptitud exigidos a los varones". Meses después, un cronista parlamentario caricaturizaba esta medida, trivializando su dimensión jurídica desde unas imaginarias cavilaciones nepotistas de los diputados: "Algunos periódicos elogian a los políticos $[\ldots]$ por haber decidido declarar a la mujer española capacitada para el desempeño de cargos públicos de elección popular. Creen esos diarios ver en esto un avance plausible en concordancia con las corrientes modernas. Rogamos a nuestros lectores que no se dejen alucinar por tales alabanzas. No somos sospechosos. Desde hace mucho tiempo venimos defendiendo en la Prensa los ideales feministas. Creemos firmemente que la mujer tiene más talento natural que el hombre, y creemos también que no puede retrasarse la hora de sus reivindicaciones. Sin embargo, hemos recibido con gran recelo la noticia de esta decisión. Todos estos políticos del viejo sistema nos inspiran una vieja desconfianza. Cuando hacen algo aparentemente bueno, pensamos: "Su cuenta les tendrá" $[\ldots][\ldots]$ En esta ocasión a que nos referimos, uno de ellos tuvo una idea genial: "—Señores — dijo a sus colegas-: disfrutamos de pingües sueldos, hasta el punto de no poder desempeñar ya más cargos. Nuestros hijos ocupan igualmente puestos retribuidos. Nuestros yernos gozan de análogo momios. Engordan con parecidas prebendas nuestros sobrinos y cuñados. La Providencia nos ha permitido igualmente colocar en los ministerios con emolumentos decorosos a nuestros cocineros y ayudantes de cámara. No podemos humanamente instalar a ningún allegado más del sexo masculino porque todos están colocados. Pero nos quedan aún nuestras hijas, nuestras hermanas, nuestras esposas, nuestras nueras, nuestras sobrinas y nuestras criadas. Ahí hay un rico filón por explotar. Declaremos la capacidad de la mujer para los cargos públicos". Un aplauso cerrado ahogó las últimas palabras del orador. Y todo quedó decidido. Verdaderamente, los hijos han sacado a los políticos españoles de grandes apuros. La frase de que cada retoño trae un pan debajo del brazo la ha inventado un ministro de la Corona. Abusando de la facultad de reproducirse que la Naturaleza les concede han resuelto el problema de monopolizar cargos incompatibles. Ellos usufructúan las carteras; sus hijos, las subsecretarías y direcciones; sus sobrinos, ls inspecciones generales; sus ser- 
sólo en 1961 se regula su ingreso en las plazas de la Administración Pública ${ }^{115}$, salvo en las de la Administración de Justicia para los cargos de juez, magistrado y fiscal ${ }^{116}$, a los que las mujeres no podrán aspirar hasta $1966^{117}$. Y salvo para el acceso a los Cuerpos y Armas de los tres Ejércitos, Institutos Armados y Cuerpos cuyo servicio implique el uso habitual de armas ${ }^{118}$, prohibición que sólo desaparecerá en $1988^{119}$.

También en el curso de los últimos años se han ido abriendo camino legal, trabajosamente, avances trascendentales en la esfera de los derechos civiles. En el año 1958, una importante reforma del Código civil introdujo señaladas modificaciones entre las que destacan el reconocimiento de la capacidad de las mujeres para ser testigos en los testamentos ${ }^{120}$ y un tratamiento igualitario de los efectos civiles del adulterio en materia de separación matrimonial ${ }^{121}$.

vidores, las jefaturas de negociado [...] Muchos que no han tenido descendencia varonil, han prohijado incluseros. Ahora se prepara una nueva invasión. Gemirán los presupuestos bajo la carga de millares de mujeres emparentadas con políticos influyentes y que no harán nada que tenga utilidad." (W. Fernández Flórez, Acotaciones de un oyente. Madrid 1963, VIII, 10 enero 1918: "Las hijas políticas").

${ }^{115}$ Ley de 22 de julio de 1961 (BOE de 24 de julio), 1: "La ley reconoce a la mujer los mismos derechos que al varón para el ejercicio de toda clase de actividades políticas, profesionales y de trabajo, sin más limitaciones que las establecidas en la presente Ley."; pero en el preámbulo se justifica ya la serie de excepciones contenidas en los artículos siguientes a esta programática declaración de igualdad laboral con el hombre: "[...] las limitaciones que en la misma se establecen al principio están basadas en hechos o circunstancias naturales de tan fácil y obvia comprensión que resulta redundante e inútil su justificación en detalle...".

${ }^{116}$ Ley de 22 de julio de 1961, 3: "Uno. En las mismas condiciones que el hombre, la mujer puede participar en oposiciones, concursos-oposiciones y cualesquiera otros sistemas para la provisión de plazas de cualesquiera Administraciones públicas. Asimismo tendrá acceso a todos los grados de la enseñanza. Dos. Se exceptúan de lo dispuesto en el número uno de este artículo el ingreso en: c) La Administración de Justicia en los cargos de Magistrados, Jueces y Fiscales, salvo en las jurisdicciones tutelar de menores y laboral".

${ }^{117}$ Ley de 28 de diciembre de 1966 (BOE de 29 de diciembre), artículo único. La limitación que ahora se deroga, explica el preámbulo "respondió no a la idea de una falta de capacidad o responsabilidad de la mujer para desempeñar tales cargos, sino más bien a la protección de sus sentimientos ante determinadas actuaciones que el cumplimiento del deber haría ineludibles. Los motivos de la protección que la Ley quiso dispensar a los sentimientos de la mujer deben estimarse superados por la propia realidad social y porque la mujer que se sienta llamada al ejercicio de la función judicial habrá de encontrar en ella ocasiones de satisfacer su vocación, que la compensarán de las aflicciones que pueda depararle."

${ }^{118}$ Ley de 22 de julio de 1961, 3.2: “. Se exceptúan de lo dispuesto en el número uno de este artículo el ingreso en: a) Las Armas y Cuerpos de los Ejércitos de Tierra, Mar y Aire, salvo que por disposición especial expresa se conceda a la mujer el acceso a servicios especiales de los mismos. b) Los Institutos armados y Cuerpos, servicios o carreras que impliquen normalmente utilización de armas para el desempeño de sus funciones. d) El personal titulado de la Marina Mercante, excepto las funciones sanitarias".

${ }^{119}$ R. Decreto de 22 de febrero de 1988 (BOE de 23 de febrero), 1-4.

${ }^{120}$ Código civil , art. 681: "No podrán ser testigos en los testamentos: $1^{\circ}$. Las mujeres, salvo lo dispuesto en artículo 701" [el referente al otorgado en caso de epidemia]; la reforma de 24 de abril de 1958 no incluye ya a las mujeres entre los incapacitados.

${ }^{121}$ Código civil (reforma de 24 de abril de 1958), art. 104: "Las causas legítimas de separación son: $1^{\text {a }}$. El adulterio de cualquiera de los cónyuges". 
Desde 1975 dejaron de estar inhabilitadas para el desempeño de la tutela ${ }^{122}$, pero los avances más significativos se impulsan en el año 1981, cuando la tradicional fórmula consagratoria de la primacía marital que hemos visto (el marido debe proteger a la mujer, y ésta obedecer al marido ${ }^{123}$ ) fue sustituida por otra más acorde con las modernas corrientes igualitarias, que es la que hoy recoge nuestro Código civil: $E l$ marido y la mujer deben respetarse y ayudarse mutuamente y actuar en interés de la familia $^{124}$. Las reformas de 1981 sancionaron también la igualdad de derechos entre los cónyuges ${ }^{125} \mathrm{y}$, en consecuencia, quedó suprimida la facultad que asistía al varón de fijar el domicilio conyugal ${ }^{126}$, definió ya la patria potestad como un poder compartido por el padre y por la madre ${ }^{127}$, implantó la administración conjunta de los bienes gananciales ${ }^{128}$, quedó reconocida la plena capacidad de la mujer para disponer de sus bienes propios y para defenderlos procesalmente sin necesidad de la licencia del marido ${ }^{129}$, y desapareció también por fin la prohibición del matrimonio de las viudas dentro de los 301 días del tempus lugendi $i^{130}$.

De este modo resultaron, por fin, definitivamente desmantelados en 1981 los principios medievales que el libro de las Partidas dejó formulados en el siglo XIII y que se habían mantenido en vigor hasta entonces, puede decirse que sin sensibles alteraciones.

Un último reducto jurídico de discriminación, localizado en la esfera del derecho laboral, también ha ido cediendo por fin en los últimos años, al amparo de los convenios internacionales suscritos por España ${ }^{131}$, de la vigencia del artículo 14 de nuestra

${ }^{122}$ Código civil, art. 237: "No pueden ser tutores ni protutores: [...] $7^{\circ}$. Las mujeres, salvo los casos en que la ley las llama expresamente; (reforma de 24 de abril de 1958): "[...] Séptimo. Las mujeres casadas que no hubieren obtenido licencia de su marido"; la referencia a las mujeres desaparece tras la reforma introducida por Ley de 2 de mayo de 1975.

${ }^{123}$ Código civil, art. 57; vid. nota 46.

${ }^{124}$ Código civil (reforma de 7 de julio de 1981), art. 67, que retoca levemente la modificación introducida en el originario art. 57 por ley de 2 de mayo de 1975: "El marido y la mujer se deben respeto y protección recíprocos, y actuarán siempre en interés de la familia".

${ }^{125}$ Código civil (reforma de 7 de julio de 1981), art. 66: "El marido y la mujer son iguales en derechos y deberes".

${ }^{126}$ Código civil (reforma de 7 de julio de 1981), art. 70: "Los cónyuges fijarán de común acuerdo el domicilio conyugal y, en caso de discrepancia, resolverá el Juez, teniendo en cuenta el interés de la familia". ${ }^{127}$ Código civil (reforma de 13 de mayo de 1981), art. 154: "Los hijos no emancipados están bajo la potestad del padre y de la madre...".

${ }^{128}$ Código civil (reforma de 13 de mayo de 1981), art. 1375: "En defecto de pacto en capitulaciones, la gestión y disposiciones de los bienes gananciales corresponde conjuntamente a los cónyuges...".

${ }^{129}$ Código civil (reforma de 7 de julio de 1981), art. 66 cit., y 71: "Ninguno de los cónyuges puede atribuirse la representación del otro sin que le hubiere sido transferida."

${ }^{130}$ Código civil (reforma de 7 de julio de 1981), art. 46: "No pueden contraer matrimonio: $1^{\circ}$. Los menores de edad no emancipados. $2^{\circ}$. Los que estén ligados con vínculo matrimonial”. Ha desaparecido la referencia a la viuda del art. 45 original, que se mantuvo intacto después de la reforma de 1958; vid. nota 75. ${ }^{131}$ Por ejemplo, y para citar sólo aquéllos a los que el legislador español más se remite, la Convención para la eliminación de todas las formas de discriminación contra la mujer, aprobada por la Asamblea General de las Naciones Unidas el 18 de diciembre de 1979 y ratificada por España en 1984; las III y 
Constitución y de la interpretación jurisprudencial que de este artículo ha venido haciendo el Tribunal Constitucional.

Este Tribunal, en sucesivas sentencias, ha sancionado, en efecto, la inconstitucionalidad de todo tratamiento de desigualdad por razón del sexo en materia de retribuciones, de jornada laboral, categorías profesionales, régimen de ascensos y demás condiciones de trabajo. Únicamente se admiten como legítimas las denominadas "discriminaciones benignas" o "positivas", es decir, las relacionadas con el embarazo y la maternidad: derecho a un descanso de varias semanas después del parto, pausa diaria para la lactancia, permisos retribuidos para exámenes prenatales y técnicas de preparación al parto y alejamiento de trabajos peligrosos mientras dure el embarazo. En todo lo demás, igualdad absoluta ${ }^{132}$.

Una denominada Ley de paridad ha venido a poner punto final, ya en el siglo XXI, a la secular historia de marginaciones que acabamos de repasar ${ }^{133}$. Entre otras medidas, la imposición a los poderes públicos de respetar una proporción equilibrada entre hombres y mujeres en los nombramientos para cargos directivos de la Administración y de los organismos públicos dependientes de ella (art. 16), a los partidos políticos en la elaboración de las listas electorales (art. 14) y la recomendación a las empresas de observar el mismo criterio en la elección de sus órganos directivos (art. 50) han instalado a las mujeres en un régimen de plena equiparación legal con los hombres. Aunque la

IV Conferencia Mundial sobre la Mujer de Nairobi en 1985, y de Beijing en 1995; Directivas del Consejo de la Unión Europea 2004/113 (Diario Oficial de 21 de diciembre) por la que se aplica el principio de Igualdad de trato entre hombres y mujeres al acceso de bienes y servicios y su suministro y 76/207 (Diario Oficial de 14 de febrero) sobre Igualdad de trato en lo que se refiere al acceso al empleo, a la formación y a la promoción profesional, etc.

${ }^{132}$ Una teórica igualdad laboral de la mujer en la esfera laboral, con las excepciones que hemos visto, había proclamado la citada Ley de 22 de julio de 1961, 4: "Uno. La mujer podrá celebrar toda clase de contratos de trabajo. En las reglamentaciones de trabajo, convenios colectivos y reglamentos de empresa no se hará discriminación alguna en perjuicio del sexo o del estado civil, aunque este último se altere en el curso de la relación laboral. Las disposiciones reglamentarias determinarán los trabajos que, por su carácter penoso, peligroso o insalubre, deben quedar exceptuados a la mujer. Dos. Las disposiciones laborales reconocerán el principio de igualdad de retribución de los trabajos de valor igual"; Constitución española, 14: "Los españoles son iguales ante la Ley, sin que pueda prevalecer discriminación alguna por razón de nacimiento, raza, sexo, religión, opinión o cualquier otra condición o circunstancia personal o social"; entre las decenas de sentencias del Tribunal Constitucional sobre este punto, pueden verse las siguientes: 8/1983 (BOE de 23 de marzo de 1983), 13/1983 (BOE de 23 de marzo de 1983), 15/1983 (BOE de 12 de abril de 1983), 86/1983 (BOE de 7 de noviembre de 1983), 75/1988 (BOE de 25 de mayo de 1988), 145/1991 (BOE de 22 de julio de 1991), 229/1992 (BOE de 19 de enero de 1993), 58/1994 (BOE de 24 de marzo de 1994), 173/1994 (BOE de 9 de julio de 1994), 286/1994 (BOE de 29 de noviembre de 1994), 147/1995 (BOE de 10 de noviembre de 1995), 136/1996 (BOE de 12 de agosto de 1996), 240/1999 (BOE de 20 de enero de 2000), 203/2000 (BOE de 24 de agosto de 2000), 17/2003 (BOE de 5 de marzo de 2003), 3/2007 (BOE de 15 de febrero de 2007), 17/2007 (BOE de 14 de marzo de 2007), etc., etc.

${ }^{133}$ Ley Orgánica de 22 de marzo de 2007 para la igualdad efectiva de hombres y mujeres (BOE de 23 de marzo). 
igualdad jurídica que dispone no garantiza del todo la igualdad social, porque no se desarraiga con facilidad una cultura alimentada en centenarios prejuicios discriminatorios, de los que de vez en cuando asoman todavía, aquí y allá, trazas residuales.

Y sin embargo, algunos vislumbres permiten conjeturar que, acaso por una vez, Derecho y realidad social hayan conseguido encontrar un punto de convergencia; porque si — como el axioma feminista asegura — sólo cabe hablar de verdadera igualdad cuando una mujer inepta pueda llegar tan lejos como a menudo llegan los hombres ineptos, el BOE (Sección Autoridades y Personal, Subsección Nombramientos) nos ha proporcionado en los últimos años incontestables evidencias de que, gracias a la mencionada Ley de paridad, se ha conseguido alcanzar esa meta. 